FHWA/IN/JTRP-2000/12

Final Report

A LABORATORY SENSITIVITY STUDY OF HYDRAULIC PARAMETERS IMPORTANT IN THE DEPLOYMENT OF FIXED-IN-PLACE SCOUR-MONITORING DEVICES

D. A. Lyn

E. Neseem

A. Ramachandra Rao

A. G. Altschaeffl

October 2000 
Final Report

\title{
A Laboratory Sensitivity Study of Hydraulic Parameters Important in the Deployment Of Fixed-in-Place Scour-Monitoring Devices
}

FHWA/IN/JTRP-2000/12

\author{
by \\ Dennis A. Lyn \\ E. Neseem \\ A. Ramachandra Rao \\ A. G. Altschaeffl \\ Purdue University \\ School of Civil Engineering \\ Joint Transportation Research Program \\ Project No. C-36-62I \\ File No. 9-8-9 \\ Prepared in cooperation with the \\ Indiana Department of Transportation and the \\ U.S. Department of Transportation \\ Federal Highway Administration
}

The contents of this report reflect the views of the author who is responsible for the facts and the accuracy of the data presented herein. The contents do not necessarily reflect the official views or policies of the Indiana Department of Transportation or the Federal Highway Administration at the time of publication. This report does not constitute a standard, specification, or regulation.

Purdue University

West Lafayette, Indiana 47907

October 2000 
A Laboratory Sensitivity Study of Hydraulic Parameters Important in the Deployment of Fixed-in-Place Scour-Monitoring Devices

5. Report Date

October 2000

6. Performing Organization Code

8. Performing Organization Report No.

FHWA/IN/JTRP-2000/12

10. Work Unit No.

9. Performing Organization Name and Addres

Joint Transportation Research Program

1284 Civil Engineering Building

Purdue University

West Lafayette, Indiana 47907-1284

12. Sponsoring Agency Name and Address

Indiana Department of Transportation

State Office Building

100 North Senate Avenue

Indianapolis. IN 46204
11. Contract or Grant No.

SPR-2149

13. Type of Report and Period Covered

Final Report

14. Sponsoring Agency Code

\section{Supplementary Notes}

Prepared in cooperation with the Indiana Department of Transportation and Federal Highway Administration.

\section{Abstract}

INDOT is considering the deployment of fixed scour-monitoring instrumentation as part of a systematic response to the problem of scour around bridge piers. Fixed-in-place automated scour-monitoring devices measure the depth of scour at the point where they are installed. Unless they are installed at the location where maximum scour occurs, their readings may give a misleading estimate of scour potential. This raises a number of technical issues concerning their effective deployment and the interpretation of the collected data, which should be resolved in order to maximize the benefits to INDOT from using these monitoring devices. These include the location of maximum scour under different pier configurations and hydraulic conditions, as well as possible effects due to pier skewness and exposed footings.

This report describes laboratory experiments that were performed to study these issues for various flow conditions and pier configurations. The experiments were conducted in a straight channel of rectangular cross-section located in the Hydromechanics Laboratory at Purdue University. The pier geometry was the same in all experiments, and was chosen to be similar to that of a prototype pier (in the US 52 bridge over the Wabash River), though exact scaling was not attempted. Both single and double (i.e., one upstream and one downstream) piers were studied. In general, for piers that were not skewed with respect to the flow, the location of maximum scour was as expected found in the immediate vicinity of the upstream nose of the up-stream pier. Nevertheless, even with relatively small skewness, for flow angle of attack less than or equal to $10^{\circ}$, the location of maximum scour may actually move downstream, either to the side of the pier or even away from the more upstream pier towards the downstream pier in the double-pier arrangement. Measurements at the nose of the upstream pier may therefore grossly underestimate scour in downstream regions if even slight skewness occurs during floods.

Experiments also indicated that, under clear-water conditions, an exposed footing may actually serve to arrest the deepening of the scour hole. Under the live-bed high-transport conditions more likely to prevail in Indiana streams, the experimental results suggest that this may be more questionable.

\section{Key Words}

bridge scour, skewed piers, scour monitoring, laboratory simulations.

\section{Distribution Statemen}

No restrictions. This document is available to the public through the National Technical Information Service, Springfield, VA 22161

\begin{tabular}{|c|c|c|c|}
\hline $\begin{array}{c}\text { 19. Security Classif. (of this report) } \\
\text { Unclassified }\end{array}$ & $\begin{array}{c}\text { 20. Security Classif. (of this page) } \\
\text { Unclassified }\end{array}$ & 21. No. of Pages & 37 \\
\hline
\end{tabular}

Form DOT F 1700.7 (8-69) 


\section{TECHNICAL Summary}

INDOT Research

Technology Transfer and Project Implementation Information

TRB Subject Code: 22-2 Bridge and Culvert Hydraulics

October 2000

Publication No.: FHWA/IN/JTRP-2000/12, SPR-2149

Final Report

\section{A Laboratory Sensitivity Study of Hydraulic Parameters Important in the Deployment of Fixed-in-Place Scour- Monitoring Devices}

\section{Introduction}

\begin{abstract}
INDOT is considering the deployment of fixed scour-monitoring instrumentation as part of a systematic response to the problem of scour around bridge piers and the associated FHWA mandates. Fixed-in-place automated scourmonitoring devices measure the depth of scour at the point where they are installed. Unless they are installed at the location where maximum scour occurs, their readings may give a misleading estimate of scour potential. This raises a number of technical issues concerning their effective deployment and the interpretation of the collected data, which should be resolved in order to maximize the benefits to INDOT from using these monitoring devices. These include the location of maximum scour under different pier configurations and hydraulic conditions, as well as possible effects due to pier skewness and exposed footings.
\end{abstract}

\section{Findings}

In general, for piers that were not skewed with respect to the flow, the location of maximum scour was as expected found in the immediate vicinity of the upstream nose of the up-stream pier. Nevertheless, even with relatively small skewness, for flow angle of attack less than or equal to $10^{\circ}$, the location of maximum scour may actually move downstream, either to the side of the
In order to investigate these issues, laboratory experiments were performed for various flow conditions and pier configurations. The experiments were conducted in a straight channel of rectangular cross-section located in the Hydromechanics Laboratory at Purdue University. The pier geometry was the same in all experiments, and was chosen to be similar to that of a prototype pier (in the US 52 bridge over the Wabash River), though exact scaling was not attempted. Both single and double (i.e., one upstream and one downstream) piers were studied. The same relatively uniformly sized sand was used in all experiments, which were conducted at approximately constant depth. Both clear-water and live-bed scour conditions were simulated. Measurements of bed elevations in the vicinity of the piers were obtained with a point gage.

pier or even away from the more upstream pier towards the downstream pier in the double-pier arrangement. Measurements at the nose of the upstream pier may therefore grossly underestimate scour in downstream regions if even slight skewness occurs during floods. Comparisons with available scour prediction formulae showed that two recently proposed formulae could 
underestimate the maximum scour, though the CSU equation recommended in HEC18 was found to be adequately conservative.

Experiments also indicated that, under clear-water scour conditions, an exposed footing may actually serve to arrest the deepening of the scour hole. Under the live-bed high-transport conditions more likely to prevail in Indiana streams, the experimental results suggest that this may be more questionable.

\section{Contact}

For more information:

\section{Dr. Dennis A. Lyn}

Principal Investigator

School of Civil Engineering

Purdue University

West Lafayette, IN 47907

Phone: (765) 494-9615

Fax: (765) 496-1988

\section{Indiana Department of Transportation}

Division of Research

1205 Montgomery Street

P.O. Box 2279

West Lafayette, IN 47906

Phone: (765) 463-1521

Fax: (765) 497-1665

\section{Purdue University}

Joint Transportation Research Program

School of Civil Engineering

West Lafayette, IN 47907-1284

Phone: (765) 494-9310

Fax: (765) 496-1105 


\section{Table of Contents}

CHAPTER I: INTRODUCTION AND SCOPE............................................................................... 1

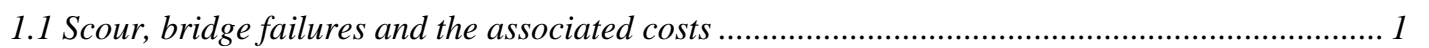

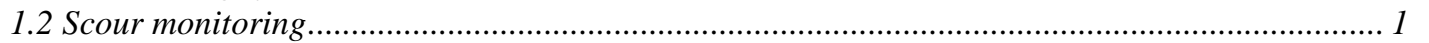

1.3 Motivation for a laboratory study ............................................................................... 2

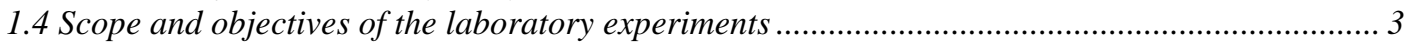

CHAPTER II: BACKGROUND AND LITERATURE REVIEW ........................................................... 4

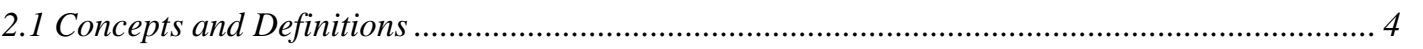

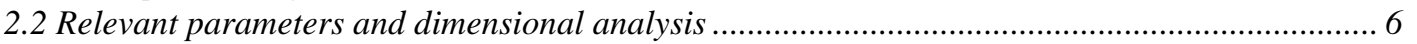

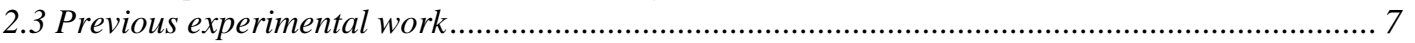

2.4 Pier scour formulae ................................................................................................. 9

CHAPTER III: EXPERIMENTAL CONSIDERATIONS.........................................................12

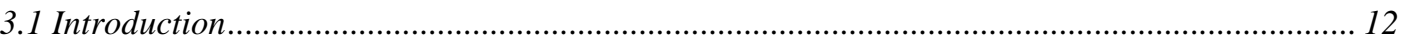

3.2 Hydrologic/Hydraulic characteristics of field sites ..................................................... 12

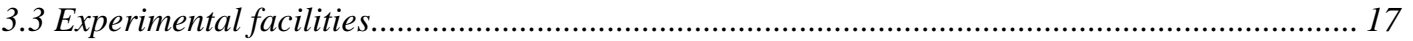

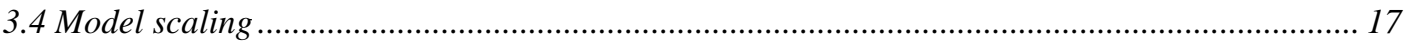

3.5 Experimental design and choice of parameters .................................................... 19

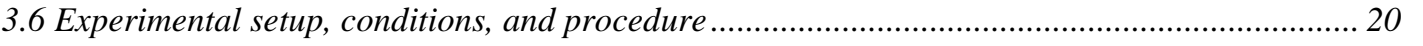

CHAPTER IV: RESULTS, ANALYSIS, AND DISCUSSION..................................................................23

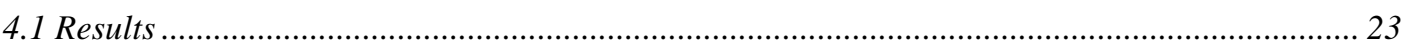

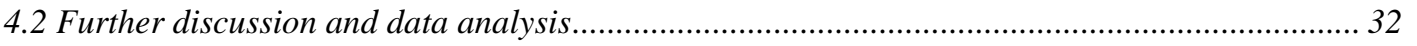

CHAPTER V: SUMMARY AND CONCLUSIONS .....................................................................35

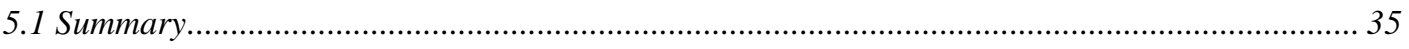

REFERENCES...................................................................................................................................36 


\section{Chapter I: Introduction and Scope}

\subsection{Scour, bridge failures and the associated costs}

Scour is a natural phenomenon caused by the erosive action of flowing water on the bed and banks of alluvial channels. Bed material, consisting of either cohesive or non-cohesive material, is entrained into the flow if the local sediment-carrying capacity of the flow is not reached. The local flow around a hydraulic structure such as a bridge pier or abutment is associated with an enhanced sediment-carrying capacity, such that scour may occur near a structure even when there is no transport of sediment away from the structure. At a bridge site, scour around bridge piers or abutments may lead to reduced support and hence constitute a potential catastrophic hazard.

The importance of bridge-related scour research reflects the large number of bridges over water, including state, country, and city as well as federal and federal-aid bridges (over 480,000 in the U.S.), and the large proportion of bridge failures attributable wholly or in part to hydraulic causes. A national study for the Federal Highway Administration (FHWA) of 383 bridge failures caused by catastrophic floods showed that 25 percent involved pier damage and 72 percent involved abutment damage (Chang, 1973). A later more extensive study (Brice and Blodgett, 1978) indicated local scour around bridge piers to be as equally important as abutment scour. During the spring floods of 1987,17 bridges in New York (including the notorious Schohaire Creek Bridge which involved several fatalities) and New England were destroyed or damaged by scour. The annual direct cost (repair and replacement cost) of flood damage for highways on the federal-aid system, which comprise less than half of the bridges in the National Bridge Inventory, has been estimated to total $\$ 50$ million (Lagasse et al., 1991 or HEC-20). This does not include indirect economic costs due, e.g., to the need to re-route traffic around a failed bridge, which may be 2 to 10 times the direct costs (Rhodes and Trent 1993).

Discussions with Indiana Dept. of Transportation (INDOT) personnel (Dougherty, personal communication) indicate that INDOT is primarily concerned with the scour around bridge piers, since these pose particular problems in repair and maintenance. The present project aims broadly to study the applicability of pier-scour monitoring as an effective means of early detection of scour problems and of providing guidance with regards to operation and maintenance priorities. It involves both field and laboratory experiments, together with mathematical modeling of the pier-scour phenomenon.

\subsection{Scour monitoring}

Because of the potential hazard due to scour, the FHWA requires that bridges be inspected for scour at intervals not exceeding two years. A scour hole is generally thought to increase in depth on the rising limb of a flood, reaching a maximum depth at or near 
peak flow. As the flood recedes, however, the scour hole may be refilled by the upstream sediment transported after the peak flow is reached. Since regular bridge inspections are generally not undertaken during periods of peak flood events but rather during low-water months, this backfilling may mask the size of the scour hole, leading to a gross underestimation of scour potential by conventional bridge inspections. Automated scour monitoring offers an alternative to periodic inspection wherein the maximum depth of scour at a fixed point is measured continuously over time, including during the peaks of floods. As such, it promises more accurate data regarding actual maximum scour, and could thus serve as part of an early warning signal system for repair and maintenance. Because scour-monitoring devices are recognized by the FHWA as an effective scour countermeasure, they may prove a flexible and cost-effective tool for INDOT in responding to FHWA mandates.

Through Project 21-3, the National Cooperative Highway Research Program (NCHRP) has funded the development of low-cost scour-monitoring devices, while the FHWA is promoting their widespread use through a demonstration project (DP-97). Two technologies have been identified as most promising for fixed-in-place scour monitoring (Lagasse et al., 1997). The first consists of a sliding magnetic collar on a pipe that is driven into the stream bed, while the second is based on a sonar device, commercially available as 'fish-finders'. Fixed-in-place scour devices however measure the scour depth at one point. Unless they are installed at the location where maximum (over a region) scour occurs, which may conceivably vary with hydraulic conditions, their readings may still substantially underestimate scour. As it would be economically infeasible to routinely install multiple devices on a single pier to map in any detail the scour pattern around it, the practical problem of selecting an optimal installation location must be confronted. In addition, the possibility that the chosen location may not actually be the location of maximum scour must also be dealt with.

\subsection{Motivation for a laboratory study}

In order to examine these issues, a laboratory study of scour around bridge piers was carried out. Although the main part of the JHRP-funded project on scour monitoring focuses on field experiments, laboratory studies can still provide complementary information and insight into the pier-scour phenomenon that might prove useful to INDOT. Due to the need for boats, positioning equipment, as well as depth measurement devices, the extensive data collection that is possible in the laboratory is difficult, time-consuming, and expensive in the field. Appropriate hydraulic conditions may also not be timely, with low flows being of less interest, and floods being too dangerous. The interpretation of field data also presents challenges due to the multitude of factors that might be relevant for any given measured event, such as the variations in the cross-sectional geometry and roughness characteristics as well as more complicated flow structures due to secondary currents. In the laboratory, experiments may be conducted under well-defined controlled conditions, and hence the effects of different factors can be isolated and studied. Being of a smaller scale, laboratory experiments can yield measurements of such detail that would be practically impossible in the field. 
A search of the literature on scour around bridge piers revealed that, while numerous laboratory studies on various topics related to pier scour have been reported, issues such as the effect of slight skewness of piers, which may have particular implications for the location of maximum depth of scour, have not received serious attention. Laboratory experiments can therefore still provide useful information, but the limitations of and difficulties associated with laboratory models should be clearly acknowledged. Because much is still ill understood regarding the basic mechanisms of pier scour, much is still controversial regarding the dominant scaling parameters. As such, questions of scale and similitude need to be considered in applying quantitatively the results of laboratory studies to the field.

\subsection{Scope and objectives of the laboratory experiments}

The laboratory study reported here forms part of a larger project investigating the usefulness of automated scour-monitoring devices. As such, it shares the broad objectives of the parent project already mentioned above. The more specific objectives of the laboratory study are principally:

- to determine the sensitivity of the location and the depth of the maximum scour to slight skewness angles,

- to assess the effect of an exposed footing under a range of conditions, and

- to study the possible problems that might be specific to double bridges (bridges with two sets of piers, one downstream of the other).

Scour around bridge piers depends on a number of parameters, and a comprehensive study of all or even the most important of these parameters will not be attempted. In particular, the direct effect of flow depth and sediment characteristics will not be considered. Similarly, the development of predictive equations describing the effects of the various parameters is beyond the scope of the laboratory study. 


\section{Chapter II: Background and Literature Review}

\subsection{Concepts and Definitions}

In discussions of scour, a number of technical terms arise frequently, and so are discussed briefly. Further details can be found in standard monographs on scour or sediment transport (Breusers and Raudkivi, 1991; Raudkivi, 1993).

\subsubsection{Types of Scour}

The total scour at a bridge crossing is conventionally evaluated in terms of three components: a) aggradation and degradation, b) contraction scour, and c) local scour. Aggradation and degradation refer to long-term tendencies of the riverbed along a certain section of the river to increase or decrease in elevation. . These may occur naturally or result from man-made changes such as construction of dams and reservoirs or changes in land use. Contraction scour occurs when the flow area of a stream is naturally or artificially reduced, e.g., due to the construction of bridge abutments. A reduction of flow area for the same discharge is generally accompanied by an increase in the flow velocity, and consequently, the sediment-carrying capacity of the flow is locally increased. This leads to sediment being entrained from the bed throughout the contracted region into the flow, until a new equilibrium is established. Whereas aggradation and degradation and contraction scour are terms applied to scour affecting an entire cross-section or an entire reach, local scour refers to patterns of erosion that are localized within a cross-section, in the immediate vicinity of natural or man-made structures, such as bridge piers or abutments. The present study is concerned solely with local scour around a pier. In the experimental design, however, it is necessary to minimize the possible effects of contraction scour and aggradation, so as not to complicate unnecessarily the interpretation of the results.

\subsubsection{Equilibrium (or Ultimate) Scour Depth}

An equilibrium pier-scour depth, to be denoted as $y_{s}$ (see Fig. 2.1 for a definition sketch), may be conceptually defined as the maximum (time-averaged) scour depth attained after the bed around the pier has been exposed to given flow conditions for a sufficiently long time. Because the time to reach an equilibrium state may, under certain conditions, be quite long, e.g., days, it is not quite clear how well this state is approximated in the field or even in the laboratory. This poses difficulties in the interpretation and correlation of laboratory and field data, since reported values in the literature may actually still reflect some dependence on time. 


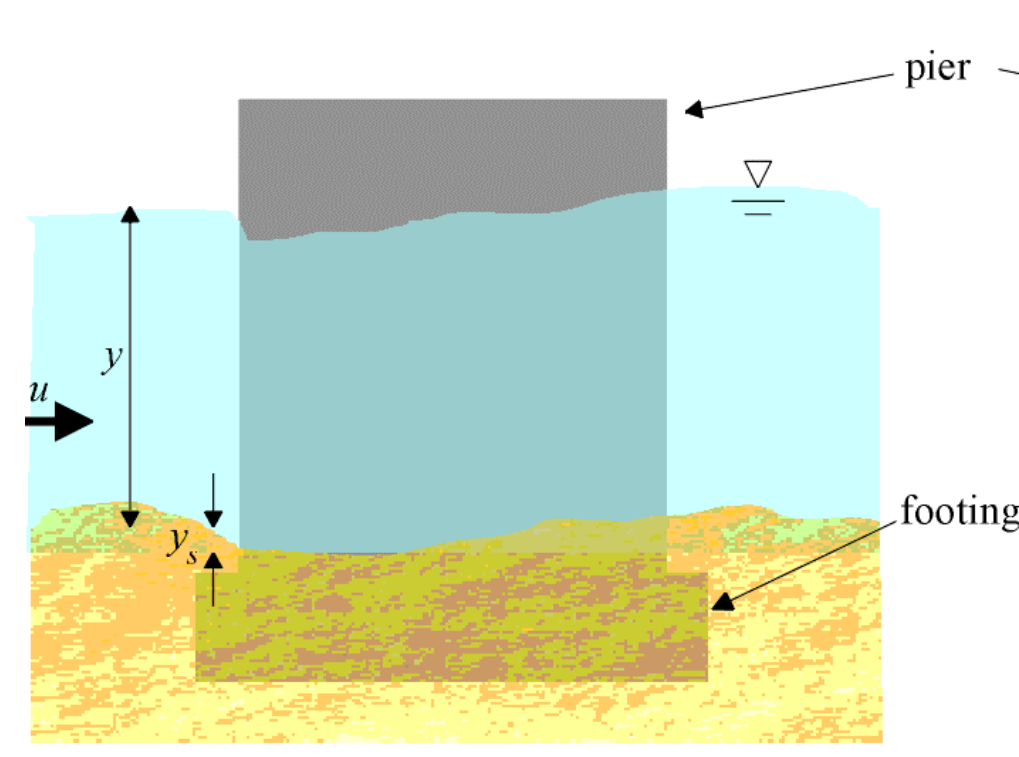

side view

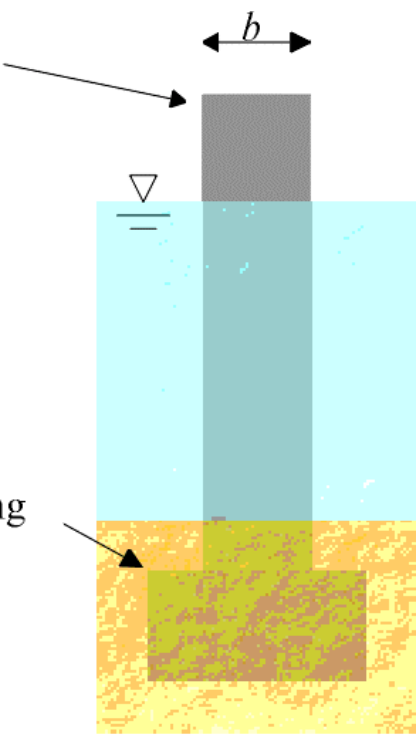

front view

Fig. 2.1 Definition sketch of pier scour

\subsubsection{Clear-Water and Live-Bed Scour}

Two types of scour, according to the condition of sediment transport in the approach flow, have traditionally been distinguished: clear-water scour, in which the approach flow carries no or a negligible amount of sediment, and live-bed scour, in which the approach flow does transport significant sediment. Clear-water scour occurs typically with a lowvelocity flow and/or larger bed material, such that the sediment-carrying capacity of the main flow is zero or negligible. Upstream and downstream of the hydraulic structure, sediment transport is therefore negligible, and only in the immediate neighborhood of the hydraulic structure is there entrainment of sediment into the flow. Because there is no upstream supply of sediment in clear-water scour, there is no refilling of the scour hole. For the conditions likely to be encountered in most Indiana streams under flood conditions, clear-water scour is unlikely to occur. Laboratory studies are however often conducted under clear-water conditions, since it is widely accepted that maximum scour is attained under these conditions (e.g., Jones et al., 1992).

Under the more probable live-bed conditions, sediment transported from upstream of the hydraulic structure may refill the scour hole, and a cyclic pattern of scour and refill may become established. The live-bed case is also complicated by the presence of bed features, which almost invariably accompany upstream sediment transport. These bed features, such as ripples and dunes, introduce mobile large-scale two-dimensional variations about the mean bed level, which would occur even in the absence of the hydraulic structure. As such, although the scour-and-fill process that characterize the movement of these bed features are not due to the pier or abutment, it may still contribute to exposing the pier (or abutment) and ultimately to the scour hazard. In the present experimental 
study, no attempt was made to distinguish between variations in bed elevation due to bed features and those due to local scour.

\subsection{Relevant parameters and dimensional analysis}

In the absence of any rigorous theoretical treatment of pier scour and a necessary dependence on experimental work, an alternative framework is needed for planning and organizing experiments (whether in the laboratory or in the field), interpreting the resulting data, and developing empirical formulae or correlations to predict scour. This may be provided by examining the relevant important parameters influencing the extent of scour and subjecting these to dimensional analysis.

The equilibrium scour depth, $y_{s}$, is expected to vary according to the characteristics of the approach flow, the bed material, and the pier. Variables (and their dimensions in square brackets) commonly thought to influence $y_{s}$ may be listed in functional form as (e.g., Melville and Sutherland, 1988; Raudkivi, 1990):

$$
y_{s}=f\left(u, y, d_{50}, g, b, \mu, \rho, \rho_{s}\right)
$$

where $u$ is the velocity of approach flow in the stream [L/T], $y$ the depth of flow [L], $d_{50}$ a representative size or diameter of the bed material [L], $g$ the gravitational acceleration $\left[\mathrm{L} / \mathrm{T}^{2}\right], b$ the (effective) pier width $[\mathrm{L}], \mu$ the dynamic viscosity $[\mathrm{M} / \mathrm{LT}]$, and $\rho_{s}$ and $\rho$ the sediment and fluid densities $\left[\mathrm{M} / \mathrm{L}^{3}\right]$ respectively (see Fig. 2.1). Here the shape and alignment of the pier as well as the grain size non-uniformity are not considered.

Dimensional analysis, through the use of the Buckingham-Pi theorem, can then be applied to form dimensionless groups, and the result can be expressed in functional form as:

$$
\frac{y_{s}}{b}=f\left(\frac{\rho u b}{\mu}, \frac{u^{2}}{g y}, \frac{y}{b}, \frac{b}{d_{50}}, \frac{\rho_{s}}{\rho}\right) .
$$

It is frequently argued that the effects of the pier Reynolds number, $\operatorname{Re}_{b}=\rho u b / \mu$, are negligible for fully turbulent flows (Melville and Sutherland, 1988; Ettema et al. 1996), and so can be omitted. For sands of primarily quartz composition, the density ratio, $\rho_{s} / \rho$, can be taken as essentially constant, so that it too can be omitted to yield

$$
\frac{y_{s}}{b}=f\left(\frac{u^{2}}{g y}, \frac{y}{b}, \frac{b}{d_{50}}\right) \text {. }
$$


The dimensionless scour depth is therefore taken to be a function of the Froude number, $F r=u / \sqrt{g y}$, the relative flow depth, $y / b$, and the pier-width to grain size ratio, $b / d_{50}$. A dimensionless parameter, often chosen instead of $F r^{2}$, is $u^{2} / g d_{50}$, which in recent work has been related to the concept of a flow intensity, $u / u_{c}$, which has gained popularity in discussions of pier scour (Johnson, 1995; Landers and Mueller, 1996). Here, $u_{c}$ is the critical velocity, describing the threshold condition beyond which sediment motion begins. $u_{c}$ and $g d_{50}$ are closely related through a correlation such as the Shields curve for incipient sediment motion. An alternative formal relationship can therefore be expressed in terms of the flow intensity rather than the Froude number:

$$
\frac{y_{s}}{b}=f\left(\frac{u}{u_{c}}, \frac{y}{b}, \frac{b}{d_{50}}\right) .
$$

The functional relationship expressed in Eqn. 2.2.3 or in Eqn. 2.2.4 (or possibly other variants) has been the basis of many correlations for the scour depth, and is also relevant to the design of laboratory experiments to study pier scour.

\subsection{Previous experimental work}

The complexity of the hydrodynamics associated with the turbulent flow around piers, not to mention the complications in predicting sediment transport, has precluded any rigorous treatment of the problem of bridge-pier scour. Instead, hydraulic engineers have relied on empirical relations based primarily on laboratory experiments, but also on an increasing body of field data. Because of the inherent complexity of field phenomena and the associated deficiencies such as sparsity and incompleteness in field data, there remains considerable uncertainty regarding the relative importance of various parameters. Many experimental studies have been performed on different aspects of bridge-pier scour, and the following review highlights only the most well-known, the most recent, or those considered particularly relevant to the present project. The large bulk of the studies have been performed with piers of circular cross-section, so that, in the following, unless otherwise specified, it may be assumed that the cited study was restricted to circular piers.

\subsubsection{Laboratory studies}

The early studies of Chabert and Engeldinger (1956) and Laursen and Toch (1956) have strongly influenced subsequent work on the topic of pier scour. The former observed that the maximum $y_{s}$ occurred under clear-water conditions, and the equilibrium state was attained monotonically. In contrast, under live-bed conditions, the equilibrium state exhibited a cyclic behavior associated with the passage of bed features. The latter concluded that, under live-bed scour conditions, the velocity did not play a significant role, and it was primarily the geometrical relationships, such as $y / b$, that were 
important. In addition to studying the effect of exposed footings, Laursen and Toch (1956) also remains one of the few studies of the effect of skewness on pier scour.

In a study of clear-water scour, Raudkivi and Ettema (1983) concluded that $y_{s} / b$ is in general a function of $y / b$ and $b / d_{50}$, where $d_{50}$ is the median sediment size. For deeper flows $(y / b>3-6)$ or finer material $\left(b / d_{50}>25\right)$, the effects of flow depth and sediment size tended to be negligible. Melville (1984) re-examined the problem of livebed scour, and emphasized the difference between ripple-forming and non-ripple-forming cases. The conclusions of Chabert and Engeldinger (1956) that the maximum $y_{s} / b$ occurred under clear-water scour conditions were shown to apply only to non-rippleforming cases. In cases where ripples appeared on the bed, as is more typical of finer bed material, the maximum $y_{s} / b$ occurred under live-bed conditions.

A recurring issue in the laboratory measurement of $y_{s}$ concerns the length of time to reach equilibrium. Because of practical limitations, in most studies, especially the earliest, experimental runs were terminated after two to eight hours. Even recent studies, such as Jones et al. (1992), used a time period of four hours, with the justification that, after this time, the change in scour depth was negligible. Chiew and Melville (1996) considered the time development of clear-water scour, defining a time to equilibrium, $t_{e}$, as the time after which the rate of increase of scour does not exceed $0.05 b$ in the succeeding 24-hr period. They concluded that $t_{e}$ could range from $6 \mathrm{hr}$ to $70 \mathrm{hr}$, generally increasing with pier diameter and approach velocity, and that scour depths after $0.1 t_{e}$ varied between $55 \%$ and $80 \%$ of $y_{s}$.

The present study emphasizes the effects due to pier skewness and to an exposed footing, particularly with regard to the location of maximum scour. The effect of skewness is relevant only for non-circular piers. Although current bridge design practice aims to align bridge piers to the flow, this may not be completely or always achieved in practice. Skewness may occur due to lateral shifting of the flow, or may even vary with flow conditions. The pioneering work of Laursen and Toch (1956) formed the basis of the treatment of skewed piers in Richardson et al. (1990), the FHWA report on recommended scour evaluation procedures more commonly referred to as HEC-18. Mostafa et al. (1993), however, found that, under certain conditions, the correlation of Laursen and Toch underpredicted measured scour, and so they developed an alternative correlation for the skewness factor to be used in conjunction with the Melville and Sutherland (1988) equation ( $K_{a}$ in Eqn. 2.4.3 below). The problem of the location of maximum scour was not addressed. Further, these studies were concerned primarily with rather large angles of attack (here called skew angles), and the effect of small skew angles has received scant attention.

The effect of an exposed footing has been investigated in several recent studies. Already in 1956, Laursen and Toch observed the tendency for an exposed footing to arrest scour hole development. Jones et al. (1992) examined the effects of footing location relative to 
the undisturbed bed level, and observed that scour could be significantly reduced by footings located at or below the bed provided the footing extended far enough upstream of the pier. This was corroborated by Parola et al. (1996), who however pointed out the sensitivity of the scour depths to the footing (or foundation) geometry and position. Melville and Raudkivi (1996) cautioned against a reliance on the scour-inhibiting effects of exposed footing under conditions where the streambed may be susceptible to large degradation.

\subsubsection{Field studies}

Measurements of pier scour in the field provide an increasing source of information for the assessment of the performance of scour formulae, although they present difficulties in the interpretation of data. As Landers and Mueller (1996) point out, it is not clear how or to what extent the concept of equilibrium scour depth can be applied to measurements in the field, since temporally changing conditions, especially during floods, work against an equilibrium. Moreover, the data analysis is complicated because all of the relevant variables may be changing with each data point, thus making difficult the task of attributing a specific effect to changes in a specific variable. Nevertheless, from the data set of 139 scour depths of 90 piers collected at 44 bridges in 12 states under both live-bed and clear-water conditions, Landers and Mueller (1996) investigated the effects of effective pier width, flow depth, and sediment size on the scour depth. Although their results agreed in some respects with earlier laboratory results, such as in the maximum values of $y_{s} / b$, or in the correlation of $y_{s}$ with $b$, in other respects there were discrepancies. There was a surprisingly weak dependence on $\mathrm{Fr}$ and a stronger than expected dependence on $y$.

In cooperation with INDOT, the U.S.G.S. conducted a study of 'historical' scour at a number of stream crossings in Indiana using a ground-penetrating radar or a tuned acoustic transducer to probe beneath the streambed (Mueller et al., 1994). These techniques attempt to identify vertical inhomogeneities in the soil properties beneath the stream, which can then be attributed to 'historical' scour. The interpretation of the signals from these instruments and particularly the relationship between signal characteristics and past scour activity remain rather controversial. Nevertheless, the scour depths so estimated from these measurements were compared with, on the one hand, predictions based on the peak historical discharge and, on the other hand, predictions following the HEC-18 procedure. It was concluded that the recommended equations yielded a conservative prediction of total scour (in some cases, possibly excessively conservative).

\subsection{Pier scour formulae}

A large number of pier scour formulae have been proposed in the literature, and the following discussion will of necessity be quite selective, focussing on the most widely used or on those of some theoretical or historical importance. In a sense, such formulae may be interpreted as encapsulating the current qualitative understanding of the pier- 
scour phenomenon in the identification of important parameters. Especially when formulated in terms of dimensionless groups, they may be helpful in assessing the relative importance of various factors, such as the importance of Reynolds number effects. Most of these formulae have been based primarily on laboratory data, though recent work has in specific cases been based entirely on field data.

Shen et al. (1969) developed a theoretical model of pier scour, and proposed that $y_{s}$ is dependent largely on $\operatorname{Re}_{b}$, with a correlation for $y_{s}$ of the form :

$$
y_{s}=0.00073 \mathrm{Re}_{b}^{0.619}
$$

This dependence on $\mathrm{Re}_{b}$ conflicts with the more widely held view of the independence of scour depth on $\operatorname{Re}_{b}$, but as has been pointed out (Jones, 1984), the data could also support a dependence of $y_{s}$ on $F r$, namely,

$$
\frac{y_{s}}{b}=3.4\left(\frac{y}{b}\right)^{1 / 3} F r^{2 / 3} \text {. }
$$

Eqn. 2.4.2 would be more consonant with the analysis leading to Eqn. 2.2.3.

The Colorado State University (CSU) equation is recommended by the FHWA (Richardson et al., 1990, more commonly referred to as HEC-18) for pier scour calculation, and is implemented in widely used open-channel hydraulics software packages such as WSPRO and HEC-RAS. It is recommended for use in both live-bed and clear-water scour, and is expressed as

$$
\frac{y_{s}}{b}=2.0 K_{1} K_{2} K_{3}\left(\frac{y}{b}\right)^{0.35} F r^{0.43}
$$

where $K_{1}, K_{2}$, and $K_{3}$ are respectively tabulated correction factors for pier shape, for the pier skewness or angle of attack of the flow, and for bed conditions (e.g., whether bed features are present). Except for differences in the exponents, the close relationship between Eqns. 2.4.2 and 2.4.3 is readily seen. In cases where the pier is skewed with respect to the flow, $K_{2}$ increases with the angle of attack and with the length-to-width ratio of the pier. When the footing is exposed to the flow, additional correction factors may be necessary. A $K_{4}$ factor to take into account the effect of armoring has recently been added, but will not be relevant for the present study.

The design approach of Melville and Sutherland (1988) is based on an equation of the form 


$$
\frac{y_{s}}{b}=K_{I} K_{y} K_{d} K_{\sigma} K_{s} K_{a}
$$

where the various $K$ factors are graphical correlations: $K_{I}$ and $K_{y}$ model respectively the effect of flow intensity, $u / u_{c}$, and the effect of the flow-depth ratio, $y / b$, while $K_{d}$ and $K_{\sigma}$ characterize the effect of sediment size, $b / d_{50}$, and size distribution through the gradation coefficient, $\sigma_{g}$, and $K_{s}$ and $K_{a}$ describe the effect of pier shape and alignment. The absence of a direct dependence on $F r$ is notable, presenting a contrast to Eqns. 2.4.2 and 2.4.3, and indicates a closer link to Eqn. 2.2.4 rather than Eqn. 2.2.3. Melville and Sutherland (1988) further developed a simplified form of Eqn. 2.4.4. For deeper flows $(y / b>2.6)$, the effect of the flow depth is negligible such that $K_{y}=1$, and, for finer sands $\left(b / d_{50}>25\right)$, the effect of grain diameters is negligible such that $K_{d}=1$. With a maximum value of 2.4 for $K_{I}$, a simplified form of Eqn. 2.4.4 can be written as

$$
\frac{y_{s}}{b}=2.4 K_{\sigma} K_{s} K_{a}
$$

A final 'design' equation for pier scour under live-bed conditions, developed by Froehlich (1988) and based entirely on a regression analysis of field data, may also be mentioned:

$$
\frac{y_{s}}{b}=0.32 K_{s}\left(\frac{b^{\prime}}{b}\right)^{0.62}\left(\frac{y}{b}\right)^{0.46}\left(\frac{b}{d_{50}}\right)^{0.08} F r^{0.20}+1
$$

Here, $K_{s}$ is again a factor modeling the effect of pier shape and $b^{\prime}$ is the projected width of the pier, the effect of skew being related entirely to the increase in project width. Regression analysis provided the first term on the right hand side of Eqn. 2.4.6, while the addition of 1 converts it to a conservative design equation which predicts a scour depth larger than any found in the data set on which the regression was based. Eqn. 2.4.6, with its dependence on $F r$, is clearly motivated by Eqn. 2.2.3, yet the magnitude of its exponents is consistent with recent analysis of field and laboratory data. The exponent on $\mathrm{Fr}$ indicates a weaker dependence on $\mathrm{Fr}$ than in the more traditional CSU equation (Eqn. 2.4.3), while the very small exponent associated with $b / d_{50}$ reflects an apparent insensitivity to grain size. Froehlich (1988) indicated that the data on which Eqn. 2.4.6 is based were obtained for sustained high-flow events, but it is not clear that these were obtained during these events. As such, whether the measured scour corresponded to actual maximum scour during flood events is still subject to some question. Although not officially recommended in the FHWA HEC-18 report for scour computations, the Froehlich equation is available as an option in the latest version of the HEC-RAS software (Version 2.0). 


\section{Chapter III: Experimental Considerations}

\subsection{Introduction}

In the design of laboratory experiments for studying hydraulic problems, a primary question concerns the extent to which laboratory results can be applied either qualitatively or quantitatively to the field. The theoretical basis for answering this question is found in the concept of similitude, whereby application of laboratory results to the field can be justified provided geometric, kinematic and dynamic scale constraints are satisfied. In a complicated problem such as scour around a bridge pier, however, these conditions cannot be strictly met and, in practice, only approximate similitude can be achieved. In this limited aim, only the most important (rather than all) dimensionless groups are required to be the same in prototype and model. Unfortunately, as seen in the preceding discussion of dimensionless groups and pier-scour formulae, a consensus regarding the importance of various groups has not yet reached in the literature.

The choice of the range of conditions and the questions addressed to be studied in the present work were based on the hydrologic/hydraulic characteristics of the particular sites chosen for the field study, namely the bridges on US 52 over the Wabash R. and on SR 25 over Wildcat Creek. Nevertheless, because it is hoped that the study will reach conclusions of more general applicability in the event of a wider deployment throughout Indiana of scour-monitoring devices, rigid prototype/model scaling was not followed even where this would have been practically feasible. In this chapter, the field sites and the characteristics relevant to the laboratory study are described. The available experimental facilities in the Hydromechanics Laboratory at Purdue University, which also impose constraints on the design of experiments, are then detailed. This leads to a discussion of scaling and similitude, followed by choices made regarding the range of experimental conditions.

\subsection{Hydrologic/Hydraulic characteristics of field sites}

Two bridges, one on US 52 over the Wabash R. and the other on SR25 over Wildcat Creek, were chosen as test sites for the installation of the scour monitoring equipment. The bridges were previously identified as either having experienced pier scour in the past, yet exhibiting in some respects quite distinct hydrologic/hydraulic characteristics and potential problems for scour-monitoring devices. Having been the subject of floodway studies (Corps of Engineers or COE, 1968; Federal Emergency Management Association

or FEMA, 1980), the hydrological characteristics of both the Wabash R. and Wildcat Creek are well known. The differences in characteristics of the two sites offered the possibility of studying a range of conditions that might be encountered in a wider 


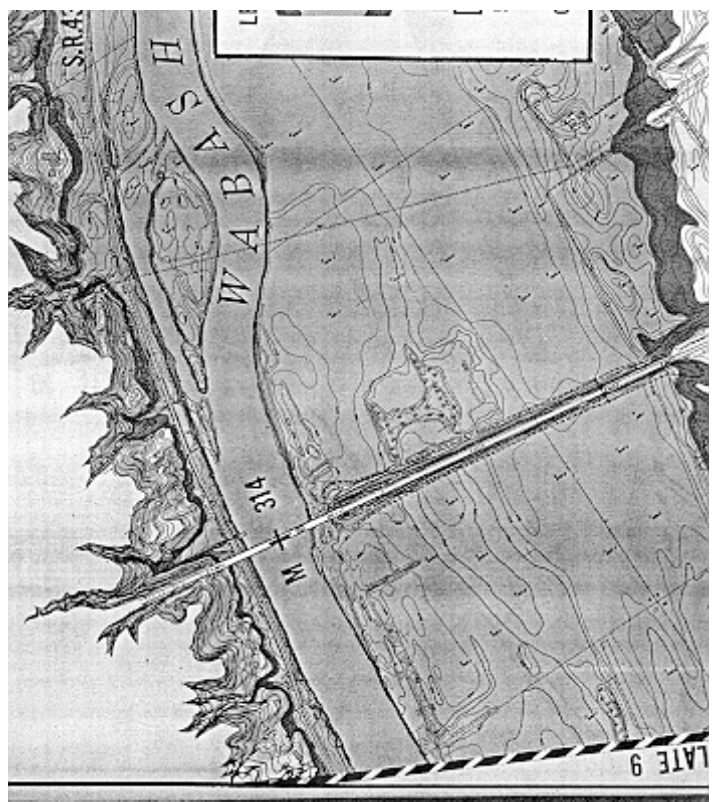

a)

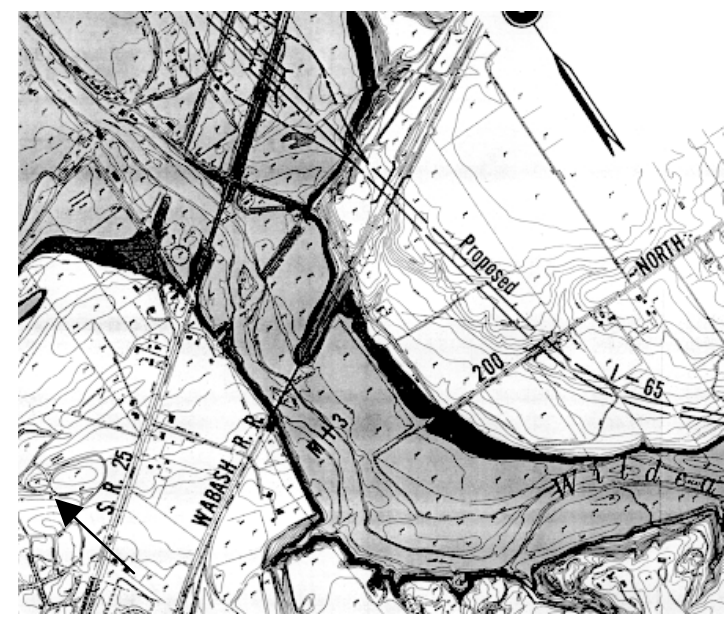

b)

Fig. 3.1 Maps of the bridge sites: a) US 52 over the Wabash R. flowing downwards, and b) SR 25 over Wildcat Creek, flowing from right to left.

deployment of scour-monitoring devices in Indiana. As a practical matter, the proximity of these two bridges to U.S.G.S gaging stations (one on the Wabash R. and another on Wildcat Creek) was advantageous for the determination of hydraulic conditions, while their proximity to Purdue University was convenient in the operation and maintenance of the instrumentation during the study period.

\subsubsection{The Wabash River and the US 52 bridge site}

The Wabash R. at Lafayette has a drainage area of over 7000 sq. miles of relatively flat terrain, and has an average slope of 0.00021 (1.1 ft per mile). Estimates of values of Manning's $n$ for the main channel, obtained by matching computed water surface profiles and field observations, ranged from $0.030-0.045$. The U.S.G.S. has maintained a gaging station since 1901 at Lafayette near stream mile 311.9 (for comparison, the US 52 bridge site is located near stream mile 314, see Fig. 3.1), though only since 1933 has there been an automatic recorder at that location.

Whereas the earlier COE study gives a 100-yr flood discharge (the so-called intermediate regional flood) as 112,000 cfs, the later FEMA study gives the 100-yr flood as 95,000 cfs. The 100-yr flood is used by FEMA as the base flood in considering flood plain management measures, and is also basic flood for which the HEC18 procedure is applied. HEC18 also specifies that the resulting scour estimates be checked with a 'super' flood, the 500-yr flood (which would correspond approximately to the COE standard project flood) or 1.7 times the $100-y r$ flood if the available data is insufficient to estimate a 500yr flood. The largest flood to have occurred on the Wabash R. over the last 100 years, the 

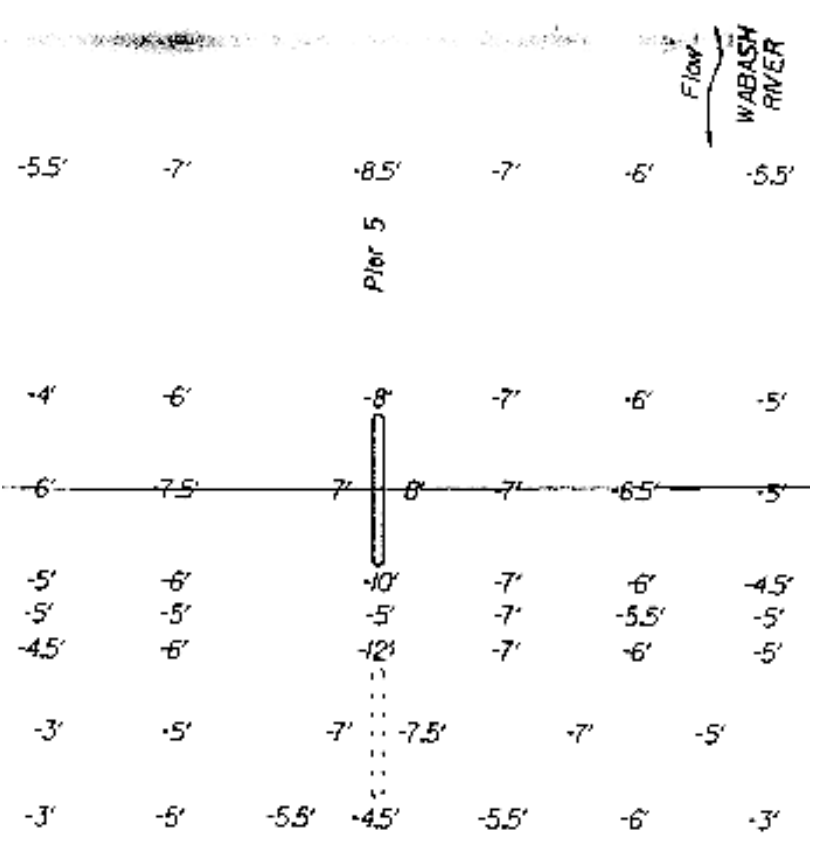

a)

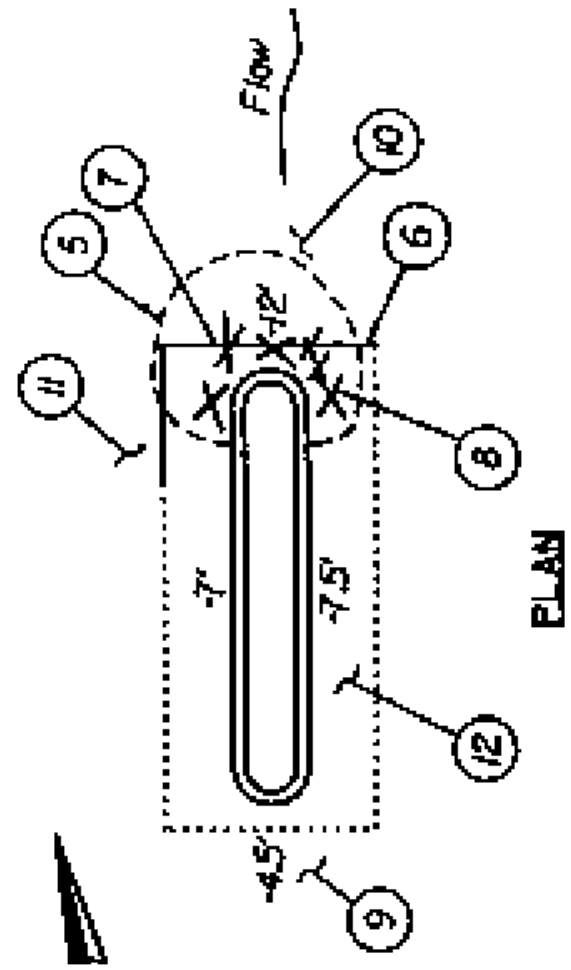

b)

Fig. 3.2 Results of bridge inspection of US 52 over the Wabash (Collins Engineers, 1994): a) bed elevations around upstream and downstream piers 5, b) expanded view of downstream pier 5 with scour hole.

1913 flood, had an estimated peak discharge of 190,000 cfs, but FEMA (1980) suggested that, with reservoirs constructed after this flood, the historically second largest flood, the 1943 flood, with a peak discharge of $131,000 \mathrm{cfs}$ would correspond more closely to a 500-yr flood. The COE study reported a flood crest elevation at US 52 of $533.8 \mathrm{ft}$ for the intermediate regional flood and $537.2 \mathrm{ft}$ for the 1943 flood (for comparison, the streambed elevation in this 1968 study was given as $500.5 \mathrm{ft}$ while the bridge floor elevation is $557.4 \mathrm{ft}$ ). The project drawings for the bridge indicate a high-water level of $535.4 \mathrm{ft}$, and a streambed level of $498.8 \mathrm{ft}$. During the $1943 \mathrm{flood}$, the river took 8 days to crest, and remained above flood stage for 19 days. In the main channel, velocities were estimated to have ranged from $5 \mathrm{fps}$ to $8 \mathrm{fps}$, increasing to $14 \mathrm{fps}$ in bridge openings.

At the site, the Wabash R. (which flows down in Fig. 3.1a) is relatively straight downstream of the bridge, but exhibits some curvature about $1300 \mathrm{ft}$ upstream. The banks of the river appear stable and well vegetated. The channel cross-section at the bridge shows a main channel of width $\approx 400 \mathrm{ft}$, and according to the 1994 bridge inspection report (Collins Engineers, 1994), sand is the predominant bed material. US 52 at the Wabash R. actually consists of two bridges approximately $67 \mathrm{ft}$ apart. The older downstream Eastbound bridge (52-79-1784 EBL), constructed about 1937, is a seven-span steel deck truss bridge with one concrete slab end span. The flow is parallel to the round-faced piers, which are tapered (the thickness range from $4.7 \mathrm{ft}$ to $7.9 \mathrm{ft}$ over a height of $43 \mathrm{ft}$ ), and are founded on concrete spread footings, some on piles. Scour holes were observed 
at two of the piers (Collins Engineers, 1994). One hole was $\approx 3 \mathrm{ft}$ deep and $\approx 5 \mathrm{ft}$ in radius, was filled with timber debris, and had exposed part of the footing. The other scour hole was $\approx 2 \mathrm{ft}$ deep and $\approx 5 \mathrm{ft}$ in radius but had not exposed the footing. Both holes were relatively symmetric about the pier, but it is notable that the scour seemed to have been more severe near the downstream pier than near the upstream (Westbound bridge) pier (Fig. 3.2).

The newer Westbound Bridge (52-79-1784 WBL), constructed in 1968, is a nine-span continuous steel girder structure. The piers are uniform in thickness $(3.75 \mathrm{ft})$ over a height of $46.25 \mathrm{ft}$. The bridge inspection report noted accumulation of timber debris along the upstream face of one of the piers, and consequently a scour hole had developed in this region. A scour hole was also evident, approximately $3 \mathrm{ft}$ in depth, at the upstream nose of another pier.

\subsubsection{Wildcat Creek and SR 25 bridge site}

Wildcat Creek flows into the Wabash R. at stream mile 317.0, where it has a drainage area of over 800 sq. miles. It has an average slope of 0.0008 (4.3 ft per mile) and the Manning's $n$ for the main channel has been estimated to be $0.040-0.055$, somewhat higher than for the Wabash R. A U.S.G.S. gaging station is located at stream mile 4.80, with continuous records available since 1954. For comparison, the SR 25 bridge is located at stream mile 2.57 .

Whereas the earlier COE study gave a 100-yr flood discharge (the so-called intermediate regional flood) as 44,800 cfs, the later FEMA study gave the significantly lower value of 28,000 cfs. The FEMA 500-yr flood was estimated as 38,500 cfs. The largest recorded peak discharge, due to the 1958 flood, was $25,000 \mathrm{cfs}$, with a crest elevation at SR 25 of $537.9 \mathrm{ft}$ and at the Wildcat Creek gaging station of $549.2 \mathrm{ft}$. The stage corresponding to the 1943 flood (before the installation of the gaging station), estimated from high-water marks, was $552.2 \mathrm{ft}$ at the station. Because of its smaller size, Wildcat Creek is subject to sharper changes in water surface levels than the Wabash R. In the 1958 flood, a maximum rate of rise of about $2 \mathrm{ft}$ per hour was observed, compared to the $1.3 \mathrm{ft}$ per hour observed in the Wabash R. Similarly, velocities in the main channel tend to be higher ranging from $7 \mathrm{fps}$ to $10 \mathrm{fps}$.

At the bridge site, Wildcat Creek (which flows upwards in Fig. 3.1b) is approximately $120 \mathrm{ft}$ wide, with somewhat steep wooded banks, and a pronounced bend upstream of the bridge. The SR 25 bridge (25-79-3881 A) over Wildcat Creek, constructed in 1952 but widened in 1977, is an eight-span (78 ft between piers), continuous steel-beam structure, supported by two end bents and seven piers. The piers, concrete shafts of width $2.5 \mathrm{ft}$ and rounded faces supported by spread footings on untreated timber piles, are skewed with respect to the bridge centerline but generally parallel to the flow direction (Fig. 3.3a). A bridge inspection report (Collins Engineers, 1997) reported scour holes on the upstream noses of two of the piers. The scour pattern at one of the piers (dry at the time of the inspection) exhibited an asymmetry, possibly indicating effects of skewness (Fig. 3.3). 


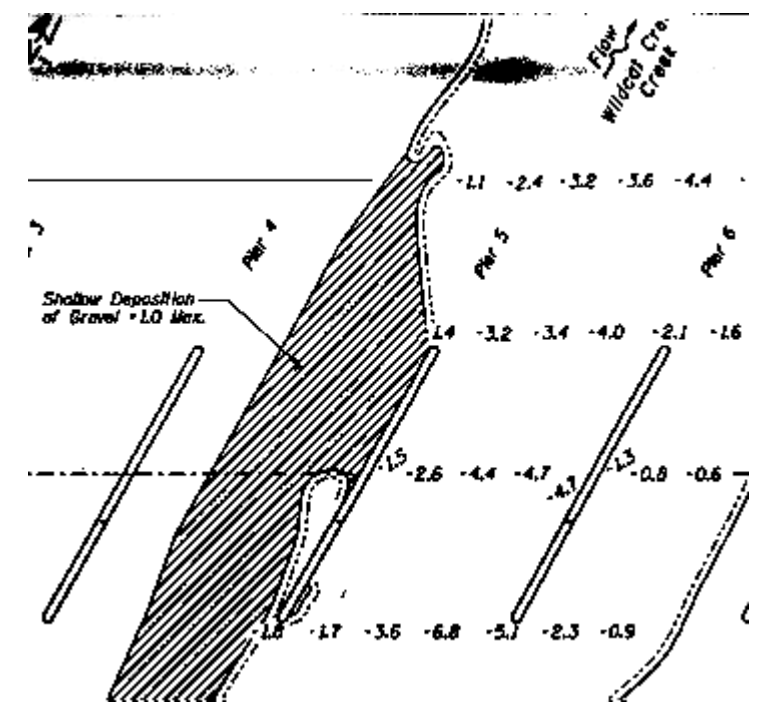

a)

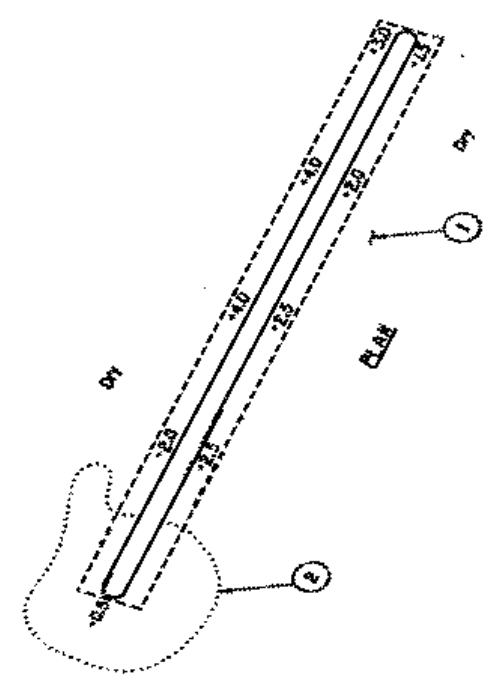

b

Fig. 3.3 Results of bridge inspection of Wildcat Creek (Collins Engineers, 1997): a) bed elevations in the vicinity of piers 4, 5, and 6, b) expanded view of pier 4 with scour hole

The hydrologic/hydraulic/pier characteristics of the two sites are compared below in Table 3.1.

\section{Table 3.1: Summary of site and pier characteristics}

\begin{tabular}{|l|c|c|}
\hline Bridge site & US 52 over the Wabash R. & SR 25 over Wildcat Creek \\
\hline Slope & 0.0002 & 0.0008 \\
\hline main channel Manning's $n$ & $0.030-0.045$ & $0.04-0.055$ \\
\hline FEMA 100-yr peak discharge & $95,000 \mathrm{cfs}$ & $28,000 \mathrm{cfs}$ \\
\hline FEMA 100-yr flood crest & $532.4 \mathrm{ft}$ & $537.0 \mathrm{ft}$ \\
\hline FEMA 100-yr flow depth & $33.6 \mathrm{ft}$ & $17.4 \mathrm{ft}$ \\
\hline main channel width & $420 \mathrm{ft}$ & $120 \mathrm{ft}$ \\
\hline main channel velocities & $6-14 \mathrm{fps}$ & $6-14 \mathrm{fps}$ \\
\hline reach characteristics & $\begin{array}{c}\text { relatively straight with } \\
\text { smooth upstream bend }\end{array}$ & sharp bend upstream \\
\hline pier thickness & $3.5^{\mathrm{b}} \mathrm{ft}$ & $2.5 \mathrm{ft}$ \\
\hline bridge span per pier & $150 \mathrm{ft}$ & $78 \mathrm{ft}$ \\
\hline pier characteristics & $\begin{array}{c}\text { rounded face, aligned with } \\
\text { flow, perpendicular to } \\
\text { bridge }\end{array}$ & $\begin{array}{c}\text { rounded face, aligned with } \\
\text { flow, skewed to bridge }\end{array}$ \\
\hline
\end{tabular}

${ }^{a}$ based on the upstream Westbound bridge 


\subsection{Experimental facilities}

The available laboratory facilities also place constraints on the experimental design and the range of experimental conditions that can be studied. The experiments were performed in a tiltable open-channel flume located in the Hydromechanics Laboratory at the School of Civil Engineering, Purdue University. The flume is straight and of rectangular cross-section, $40 \mathrm{ft}$ long, $1.5 \mathrm{ft}$ wide, $2 \mathrm{ft}$ deep, and is capable of a discharge exceeding 12 cfs, but is not capable of recirculating sediment. The side walls of the flume are transparent, thereby allowing visualization and video recording of the flow and the scour process during an experimental run. Mounted on rails along the length of the flume is a carriage, from which a point gage could be traversed.

\subsection{Model scaling}

In order to apply quantitatively the results of small-scale laboratory experiments to largescale field prototypes, the laws of similitude should be followed. Strictly speaking, this requires that geometric, kinematic, and dynamic similarity between model and prototype be preserved (Roberson and Crowe, 1993). Unfortunately, in complicated hydraulic problems such as those involving sediment transport, strict similitude cannot be practically achieved. For example, geometric similarity would imply that the sediment size must be chosen, for any reasonable scaling, so small that extraneous effects such as cohesiveness may become important. The art of hydraulic models lies in the selecting the most important dimensionless groups, and scaling according to them. In the problem of pier scour, however, amid the multiple possible dimensionless parameters, a consensus regarding the important parameters does not yet exist.

Elementary discussions of scaling and similitude (Roberson and Crowe, 1993) focus on Reynolds number and Froude number 'laws', i.e., model and prototype are scaled so that appropriate Reynolds and Froude numbers are identical in model and prototype. In traditional hydraulic modeling of open-channel flows, Froude number scaling has been preferred. While it is generally agreed in the modeling of pier scour that the pier Reynolds number, $\operatorname{Re}_{b}=\rho u b / \mu$, is not important, this assumes that the flow is sufficiently turbulent. The experiments were therefore performed under conditions for which $\operatorname{Re}_{b}$ in the model is sufficiently large, e.g., $\operatorname{Re}_{b}>2000$, so that turbulent flow could be assumed. This may be compared to values of $\mathrm{Re}_{b}$ in the field in excess of $10^{6}$. Provided the depth to pier width ratio is larger than unity $(y / b>1)$, the condition that $\operatorname{Re}_{b}>2000$ will also ensure that the flow upstream of the pier(s) was also turbulent.

The importance of the Froude number, $F r$, in pier scour problems remains controversial. The CSU equation includes a relatively strong dependence on $F r$. On the other hand, Laursen and Toch (1956) concluded that 'the Froude number does not need to be the same in the model and prototype as long as the flow in both is somewhat below a value of unity'. Recent work, such as the Melville-Sutherland design approach, the Froehlich 
equation, and the field data of Landers and Mueller, has further confirmed that the dependence on $\mathrm{Fr}$ may be much weaker than previously thought. Nevertheless, since the flow in Indiana streams under flood conditions is generally characterized by lower $F r<0.5$ (Table 3.2), it was desirable to confine the experiments to this range.

The limited width $(1.5 \mathrm{ft})$ of the laboratory flume constrains the flow depths that can be used in the model study. At large depths, the channel walls may exert a significant effect on the flow, due to the generation of secondary currents, which would complicate the interpretation of the results. On the other hand, consideration of the values of $y / b$ attained during flood conditions in the field would recommend a value of $y / b \approx 7-10$. Moreover, in this range of $y / b$, the scour depth is expected to be relatively insensitive to values of $y / b$ (Melville and Sutherland, 1988). Because the piers to be studied are noncircular, the length of the piers must also be considered, especially when the effects of pier skewness are to be studied. Since laterally adjacent piers in the field are sufficiently far apart that there is negligible interaction between them, this should also be the case in the model. Only a single pier in the cross-stream direction will be modeled, and the effect of channel walls should be negligible even when the piers are skewed to the flow. This approach is supported by the conclusions of Laursen and Toch (1956) that 'an entire river crossing need not be modeled in investigating the local scour at a pier'.

The effect of sediment size and gradation on pier scour remains a topic of research. Again, the conclusions of Laursen and Toch (1956) are instructive. They concluded that 'the same depth of scour should result in the model, no matter what velocity or sediment is used' [italics have been added]. Melville and Sutherland (1988) qualified this in arguing that, for $b / d_{50}>25$, the effects of sediment size, $d_{50}$, are negligible. The CSU equation (Eqn. 2.4.3) does not include a factor for sediment size, while the exponent of $y / d_{50}$ in the Froehlich equation (Eqn. 2.4.6) is very small, both indicating the weak direct effect of sediment size. Provided that $b / d_{50}$ is chosen equal to or larger than 25, the choice of $d_{50}$ was not expected to play a major role.

On the other hand, $d_{50}$ appears implicitly in the critical velocity, $u_{c}$, and in the distinction between live-bed and clear-water scour, and also in the difference between ripple-forming and non-ripple-forming conditions (Melville, 1984). Under flood flows in most Indiana streams, live-bed conditions are expected to prevail. Many studies of pier scour have however preferred to work with clear-water conditions because the maximum scour depth is thought to occur under these conditions. Sediment gradation, typically measured in terms of the geometric standard deviation of the size distribution, $\sigma_{g}$, also is known to affect the extent of scour. As the smaller size fractions are eroded in a scour hole, the remaining larger size fractions may form an armor layer, which inhibits further scour. Thus, for the same $d_{50}$, bed material characterized by larger values of $\sigma_{g}$ may be less susceptible to scour, and will be associated with smaller scour depths. For this reason, studies of scour with uniform sand will generally yield more conservative (larger scour depths) results than those with non-uniform sands. 


\subsection{Experimental design and choice of parameters}

The present study is primarily interested in a number of aspects related to the use of available scour-monitoring devices. These include the location of maximum scour under various conditions, including pier skewness, the location of footings, and the case of double or twin bridges. Other issues, such as the dependence on Froude number or relative depth, are either secondary or are beyond its scope, and have received much more previous attention. The limited scope of the study dictated the choice of experimental parameters.

In view of the various constraints, it was decided to perform experiments with a pier of thickness $0.042 \mathrm{ft}(0.5$ in or $1.25 \mathrm{~cm}$ ), which corresponds to a scale of $\approx 1 / 111$ for US 52 over the Wabash R. and $\approx 1 / 60$ for SR 25 over Wildcat Creek. The model piers were constructed primarily with the double piers of US 52 case in mind. The channel width to pier width ratio, $\approx 36$ (even in the case of maximum skew, $\approx 25$ ), was sufficiently large that flow contraction was negligible, and hence that contraction scour did not play any significant role. It was further decided to limit the study to a single flow depth, $0.32 \mathrm{ft}$ $(10 \mathrm{~cm})$, such that $y / b=8$, and a channel width to depth ratio of 4.5 for which the effect of sidewalls should be small.

\section{Table 3.2 Comparison of typical dimensionless parameters for model and field (under flood conditions)}

\begin{tabular}{|l|c|c|c|}
\hline $\begin{array}{l}\text { dimensionless } \\
\text { parameter }\end{array}$ & $\begin{array}{l}\text { US 52 over the } \\
\text { Wabash }\end{array}$ & $\begin{array}{l}\text { SR 25 over Wildcat } \\
\text { Creek }\end{array}$ & laboratory model \\
\hline $\mathrm{Re}_{b}=u b / v$ & $2.5 \times 10^{6}$ & $1.5 \times 10^{6}$ & $3.75 \times 10^{3}$ \\
\hline$F r=u / \sqrt{g y}$ & 0.2 & 0.25 & $0.3-0.4$ \\
\hline$y / b$ & 8.5 & 6.8 & 8 \\
\hline$b / d_{50}$ & $>25$ & $>25$ & 26 \\
\hline$u / u_{c}$ & $>1$ & $>1$ & $0.8-1.3$ \\
\hline
\end{tabular}

Note: The field values were based on FEMA values for the 100-yr flood, with values of velocity assumed to be 6 fps.

Very little precise information is available about the sediment size distribution at the sites, with only qualitative information from the bridge inspection reports (Collins Engineers, 1994, 1997) or bridge plan sheets noting that sand is predominant bed material. As a simplification, it was decided to use a relatively uniformly sized sand with a $d_{50}$ of $0.5 \mathrm{~mm}$ and a $\sigma_{g}=1.5$. Since $b / d_{50}=26$, the results should not be especially sensitive to the precise choice of $d_{50}$ (Melville and Sutherland, 1988). This choice also permitted the study of both clear-water and live-bed conditions. For $d_{50}=0.5 \mathrm{~mm}$, the critical velocity was estimated as $\approx 1 \mathrm{fps}$ using the Shields curve and a logarithmic 
velocity profile (Melville and Sutherland, 1988). With the choice of a uniform sand, effects due to armoring will not be included in the study. A comparison of various dimensionless parameters is given in Table 3.2.

\subsection{Experimental setup, conditions, and procedure}

\subsubsection{The experimental setup and the model piers+footings}

A sketch of the flume used in the experiments is shown in Fig. 3.4. Approximately $12 \mathrm{ft}$ from the entrance, a sediment box, $4 \mathrm{ft}$ long and $0.5 \mathrm{ft}$ deep, extending below the channel bottom was installed in order to permit local scour deeper than the original channel bottom. The model piers were located in the middle of the sediment box area. Outside of the sediment box area, a layer of erodible sand, approximately one inch thick, was laid over an area extending about $10 \mathrm{ft}$ upstream and downstream of the sediment box area. Because this provided a source of sediment, live-bed conditions could be approximately maintained if desired over the duration of an experimental run. Although the upstream pier on US 52 over the Wabash R. was tapered, it was decided that model piers of constant thickness would still give useful results and avoid the additional labor of machining a tapered pier. The model piers were placed on model footings, all of which were constructed from plexiglas.

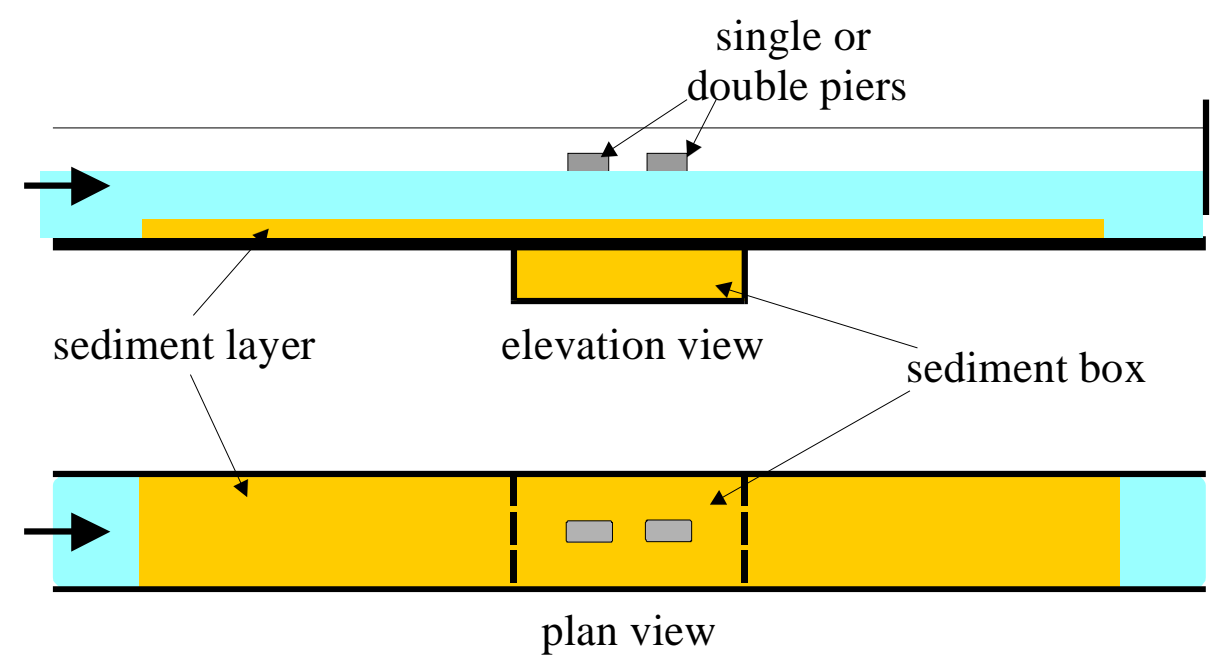

Fig. 3.4 Sketch of laboratory flume with sediment box, sediment layer and model

The geometry of model piers are shown in Fig. 3.5. In the case of double piers, the downstream pier was located $0.83 \mathrm{ft}$ from the upstream pier, and had a triangular rather than a circular nose. With a constant depth, changes in the flow velocity were achieved through a change in the discharge. The flow into the flume was provided by an constanthead tank. A sluice gate located at the end of the flume and a valve controlling the entering flow were used to regulate the flow depth and to control the discharge. Point velocity measurements were obtained with laser Doppler velocimetry (LDV) at various 
locations in the flow, including the undisturbed approach flow, from which the discharge could be estimated. Measurements of the bed levels were made using a point gage mounted on a movable carriage where a traverse mechanism was setup for this purpose.

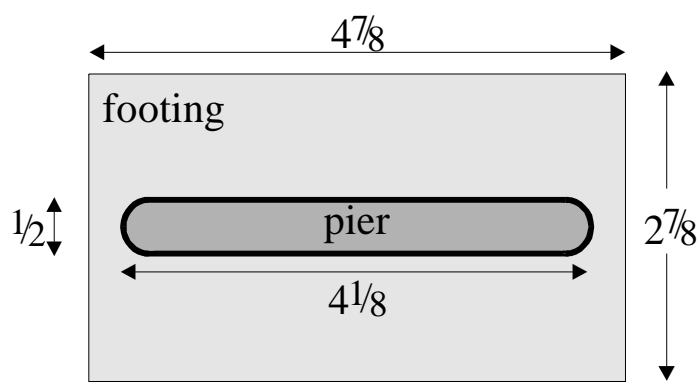

a) single or upstream pier

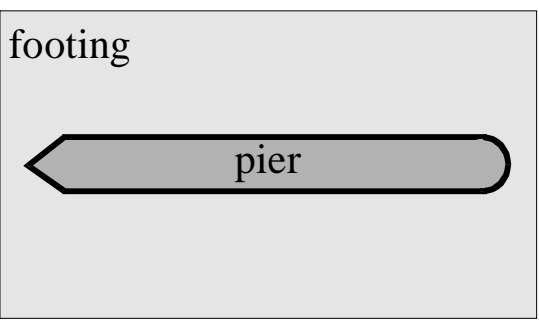

b) downstream pier

Fig. 3.5 Geometric details of the model piers (dimensions in inches)

\subsubsection{Range of experimental conditions studied}

Two series of experiments were performed, one where the skewness or flow angle of attack was set to zero, and the other with skewness slightly greater than zero (angles of attack of $5^{\circ}$ and $\left.10^{\circ}\right)$. In general, bridge piers are currently designed for zero skew, as indeed is the case for both bridges under consideration. Raudkivi (1990) recommends that, in designing for bridge scour, 'angles of attack greater than $5^{\circ}-10^{\circ}$ should be avoided'. It is also known that, for large skewness, the flow field and the resulting scour differ quite radically from that associated with the zero-skew case. In particular, the location of maximum scour and the maximum scour depth will bear no resemblance to the results of the zero-skew case. For the case of small departures from zero skew, which might occur even in the most carefully designed piers and therefore might be of more practical interest, the situation is less clear, and has been very little studied.

For zero skewness, both single and double piers were investigated, the double piers being of interest because of the case of US 52. For runs with non-zero skewness performed after the runs with zero skewness, only double piers were studied, since it was expected and confirmed by the zero-skewness runs that the effect of the downstream pier on the upstream flow was negligible. The effect of the location of the footing or alternatively the effect of an exposed footing was also investigated because one of the piers on US 52 had become partially exposed. In these runs, the footing was located initially below the erodible channel bed, but became exposed during the run. In each series, the effects of scour regime (clear-water versus live-bed conditions) and flow intensity were individually considered. The approach velocity ranged from $0.8 \mathrm{fps}$ to $1.3 \mathrm{fps}$, corresponding to a range of $u / u_{c}$ from $\approx 0.8$ to 1.3 . 


\subsubsection{Experimental procedure}

A common procedure was generally followed in each run throughout the series of experiments, though as experience was gained and the focus of the experiments shifted from unskewed single piers to skewed double piers, some minor changes in procedure were taken. The pier (or piers) was installed in the sediment box, with the footing located at a given distance below the sediment bed. The bed was leveled approximately by hand before each run and an average initial bed elevation was measured with a point gage. The flow was started, and the desired depth and velocity was obtained by a trial-and-error adjustment of the downstream gate and the inlet valve. Although care was taken to increase the discharge very gradually to the desired level, it was observed that, during the initial transient phase when the flow conditions were set up, typically lasting 30 to 50 minutes, some local scour around the bridge piers inevitably occurred.

During the course of the run, video images were taken using a camera at varying time intervals, and stored on a video recorder. In the initial runs, some flow visualization studies were performed by injecting dye just upstream of the pier. Velocity profiles were also taken using the laser Doppler velocimetry technique. In the case of the single pier with zero skew, these were taken only in the approach flow, but in the skewed cases and the cases with double piers, additional profiles were at the side of the piers and between the double piers.

The duration of each run was typically 6 hours, though at least one run was continued for 9 hours to examine the effect of run duration on the results. Most researchers have used a test duration of 2 to 8 hours, e.g., Jones et al. (1992) terminated their experiments after only four hours. Under clear-water conditions, often used in previous studies, early termination of a run may have more serious consequences because of the low transport and hence the long time to equilibrium. Under higher-transport, live-bed conditions, this is likely to pose less of a problem, but the problem of refill of the scour hole may arise. In the present study, for live-bed conditions, an attempt was made in each run to terminate the run when the scour hole was judged visually to be at or near its maximum depth. Thus, while the scour-and-refill problem is encountered in the laboratory as in the field, the laboratory study retains additional control in the choice of the time at which the run is terminated.

At the end of a run, the flow is gradually decreased in such a way as to cause minimal disturbance to the bed. The channel was drained, and after the bed was dry, typically two days after the run, the elevation of the bed was measured in the area around the pier(s) with the point gage. In runs with bed profiles, bed elevations along the centerline was obtained by averaging the readings taken along both sides. A traverse mechanism mounted on a mobile carriage was used to move the point gauge. In a single run, over 350 bed-level measurements might be manually taken. Although the point gage could be read to \pm 0.02 in, the overall measurement uncertainty is believed to be conservatively estimated as less than 0.06 in. 


\section{Chapter IV: Results, analysis, and discussion}

\subsection{Results}

\subsubsection{Cases without Skew}

Five runs were conducted, three of which were performed with a single pier, and the other two with double piers. The flow depth and the pier width were held constant at $y \approx 0.33 \mathrm{ft}(10 \mathrm{~cm})$ and $b=0.5 \mathrm{in}(1.25 \mathrm{~cm})$ respectively, but the elevation of the footing was varied. The sediment was well sorted with a median grain size of $0.5 \mathrm{~mm}$, and the critical velocity for incipient motion was estimated from the Shields curve and an assumed logarithmic velocity profile (Raudkivi, 1990) to be $1 \mathrm{fps}(30 \mathrm{~cm} / \mathrm{s})$. The experimental conditions are summarized in Table 4.1. A photograph of a case with an exposed footing (Run 3) is shown in Fig. 4.1.

Figs. $4.2-4.4$ shows the contours of the bed elevation as well as a longitudinal section through the pier centerline for Runs $1-3$, all of which were concerned with the case of a single pier. Run 1 constituted a base or benchmark case, with which the other cases were compared. In this case, upstream transport was relatively small, with $u \approx 1 \mathrm{fps}$ and

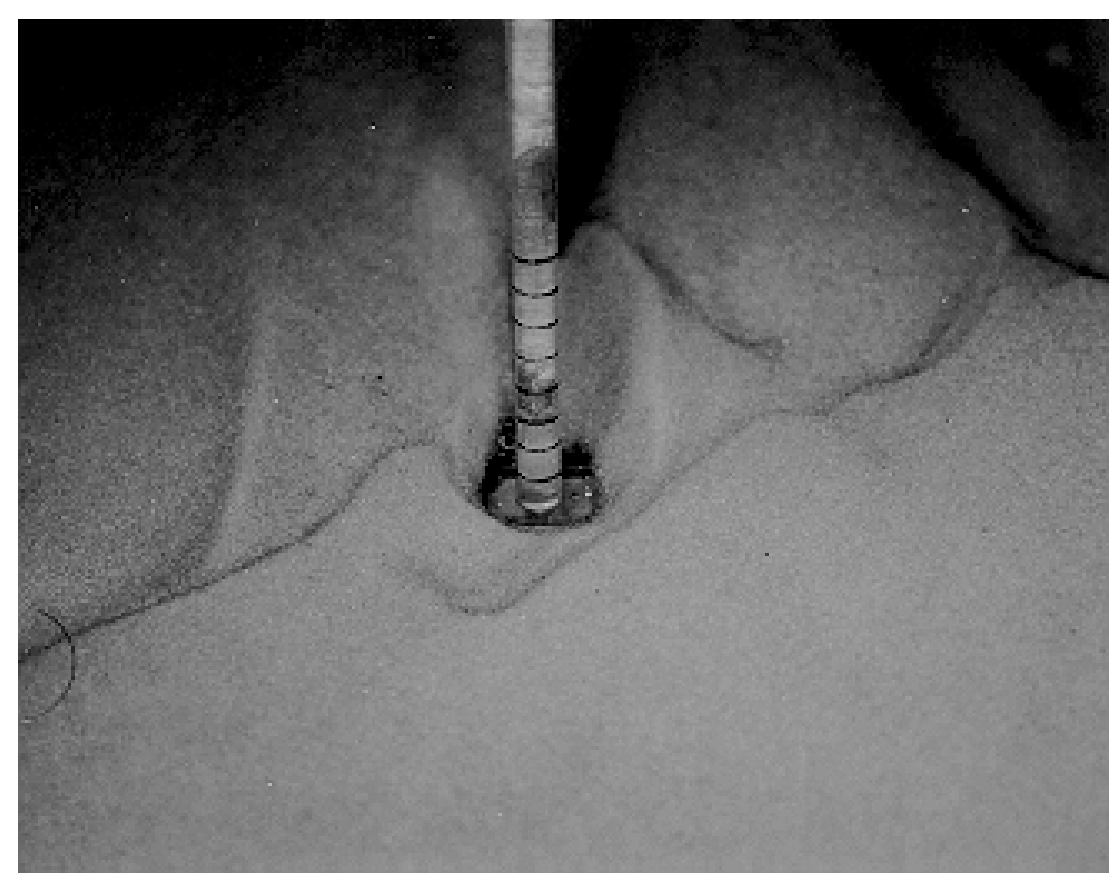

Fig. 4.1 Photograph of scour around a single zero-skew pier with an exposed footing (Run 3) 
$u / u_{c} \approx 1$, with the elevation of the footing at a level where the footing would not be exposed in the course of the run. The maximum scour was found near the pier nose, with $y_{s}=0.06 \mathrm{ft}$ (measured with respect to the mean bed level), corresponding to $y_{s} / b=1.4$. Due to the averaging procedure, the position of the maximum scour depth was slightly displaced downstream of the pier nose but video images of the run showed that the maximum scour occurred in the pier-nose region. Run 2 was run under approximately the same hydraulic conditions as in Run 1, but as with the other runs in this series, the footing was raised to a level where the footing would be exposed during the run.. The maximum scour depth was noticeably less than in Run 1 , with $y_{s}=0.023 \mathrm{ft}$ or $y_{s} / b=0.6$. An exposed footing may therefore actually serve to arrest the deepening of a scour hole, as was already pointed out by Laursen and Toch (1956) and others, e.g., Jones et al., (1993). The extent of the scour hole may however be broadened. When a somewhat higher velocity ( $u=1.5 \mathrm{fps}, u / u_{c}=1.5$ ) was imposed as in Run 3, the depth of the scour hole increased $\left(y_{s}=0.047 \mathrm{ft}, y_{s} / b=0.9\right.$ ) compared to Run 2 . The footing was also exposed in this case, so that an increase in flow intensity may still lead to a deeper scour hole even when the footing is exposed.

\section{Table 4.1: Experimental conditions for runs without skew}

\begin{tabular}{|l|c|c|c|c|c|}
\hline parameter & Run 1 & Run 2 & Run 3 & Run 4 & Run 5 \\
\hline velocity, $u$ (fps) & 1.02 & 0.98 & 1.48 & 0.79 & 0.98 \\
\hline $\begin{array}{l}\text { elevation of footing with res- } \\
\text { pect to initial bed level, } z_{f} \text { (in) }\end{array}$ & -2 & -0.2 & -0.2 & -0.3 & -0.3 \\
\hline number of piers & 1 & 1 & 1 & 2 & 2 \\
\hline $\begin{array}{l}\text { pier Reynolds number, } \\
\operatorname{Re}_{b}=u b / v\left(\times 10^{3}\right)\end{array}$ & 3.9 & 3.8 & 5.6 & 3.0 & 3.8 \\
\hline Froude number, $F r=u / \sqrt{g y}$ & 0.31 & 0.30 & 0.45 & 0.24 & 0.30 \\
\hline flow intensity, $u / u_{c}$ & 1 & 1 & 1.5 & 0.8 & 1 \\
\hline $\begin{array}{l}\text { relative elevation of footing, } \\
z_{f} / b\end{array}$ & 4 & 0.4 & 0.4 & 0.6 & 0.6 \\
\hline
\end{tabular}

Clear-water conditions prevailed in the first of the cases with two piers (Run 4) since $u / u_{c}=0.7$. This is reflected in Fig. 4.5 in the relatively featureless region upstream of the piers and the much more symmetric (about the piers) bed features. The maximum scour depth was achieved at the nose of the upstream pier, and was essentially dictated again by an exposed footing. A sheltering effect of the upstream pier on the downstream pier (Laursen and Toch, 1956) does not appear strong in Run 4, with $y_{s}$ in the wake of the upstream pier comparable though not exceeding $y_{s}$ in the nose of the upstream pier. This may however be strongly dependent on the distance between piers. A surprisingly deep scour hole was observed in the second two-pier case (Run 5) in the nose region of 

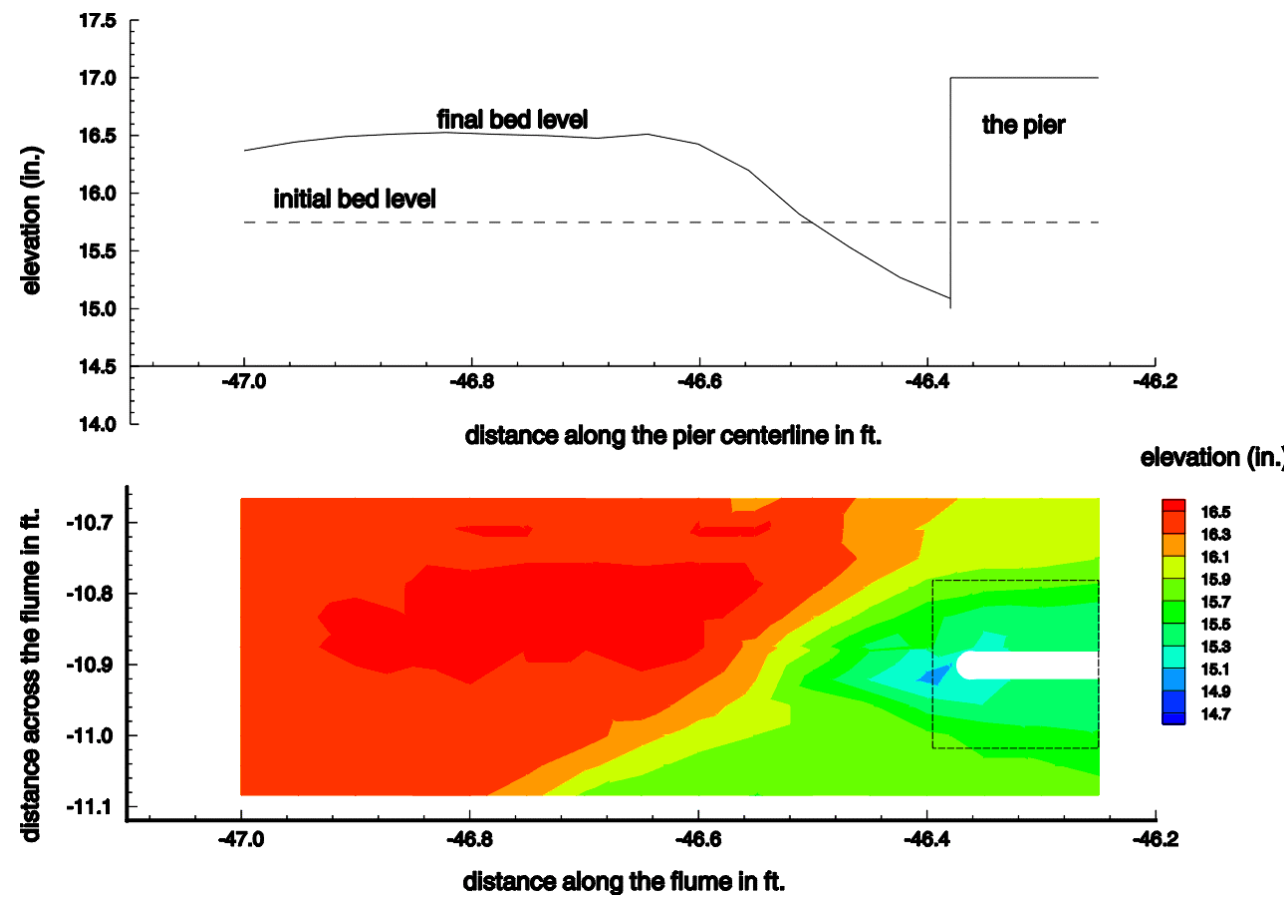

Fig. 4.2 Results for Run 1: a) bed-level profile along channel centerline (aligned with pier), b) contours of bed-level in vicinity of pier
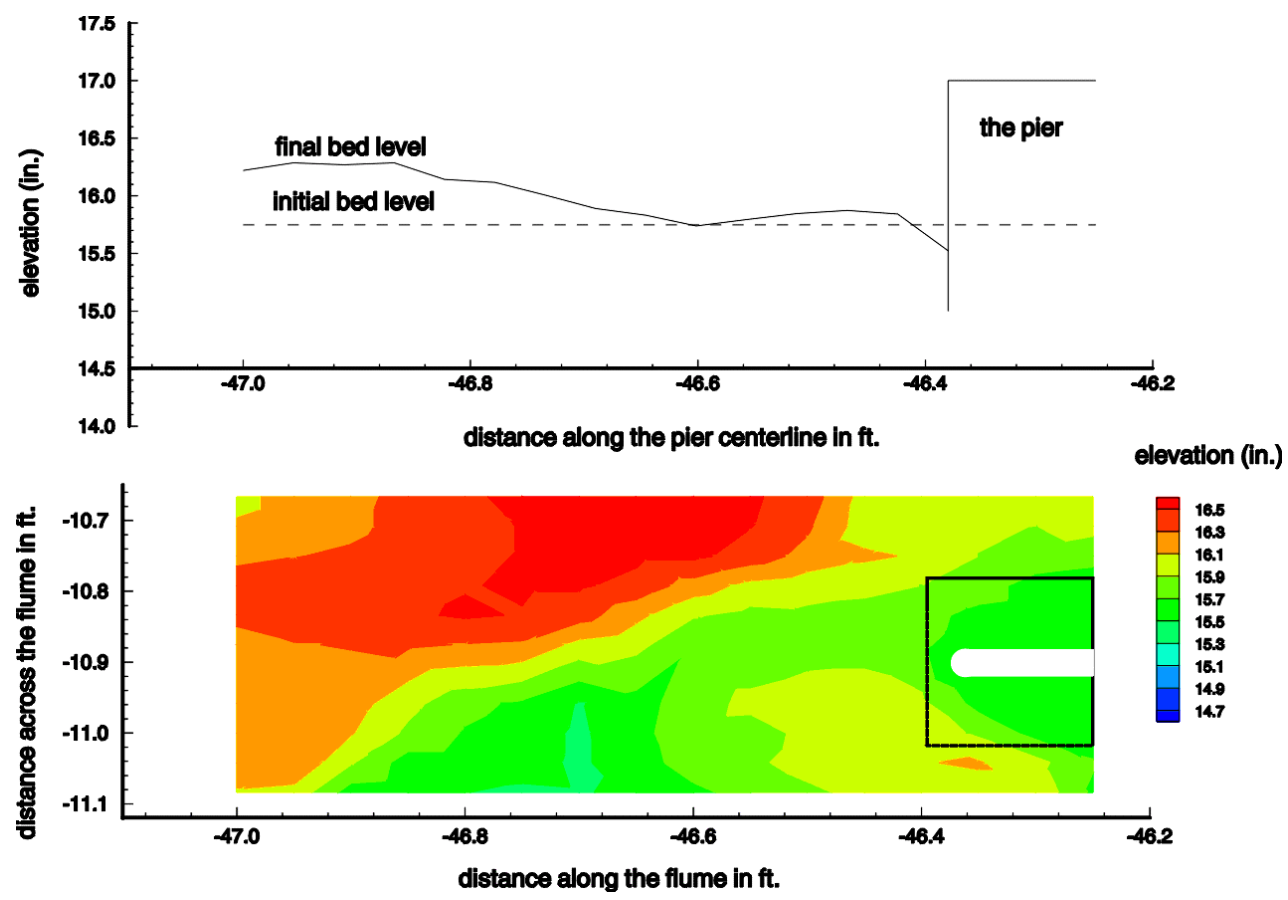

Fig. 4.3 Results for Run 2: a) bed-level profile along channel centerline (aligned with pier), b) contours of bed-level in vicinity of pier 


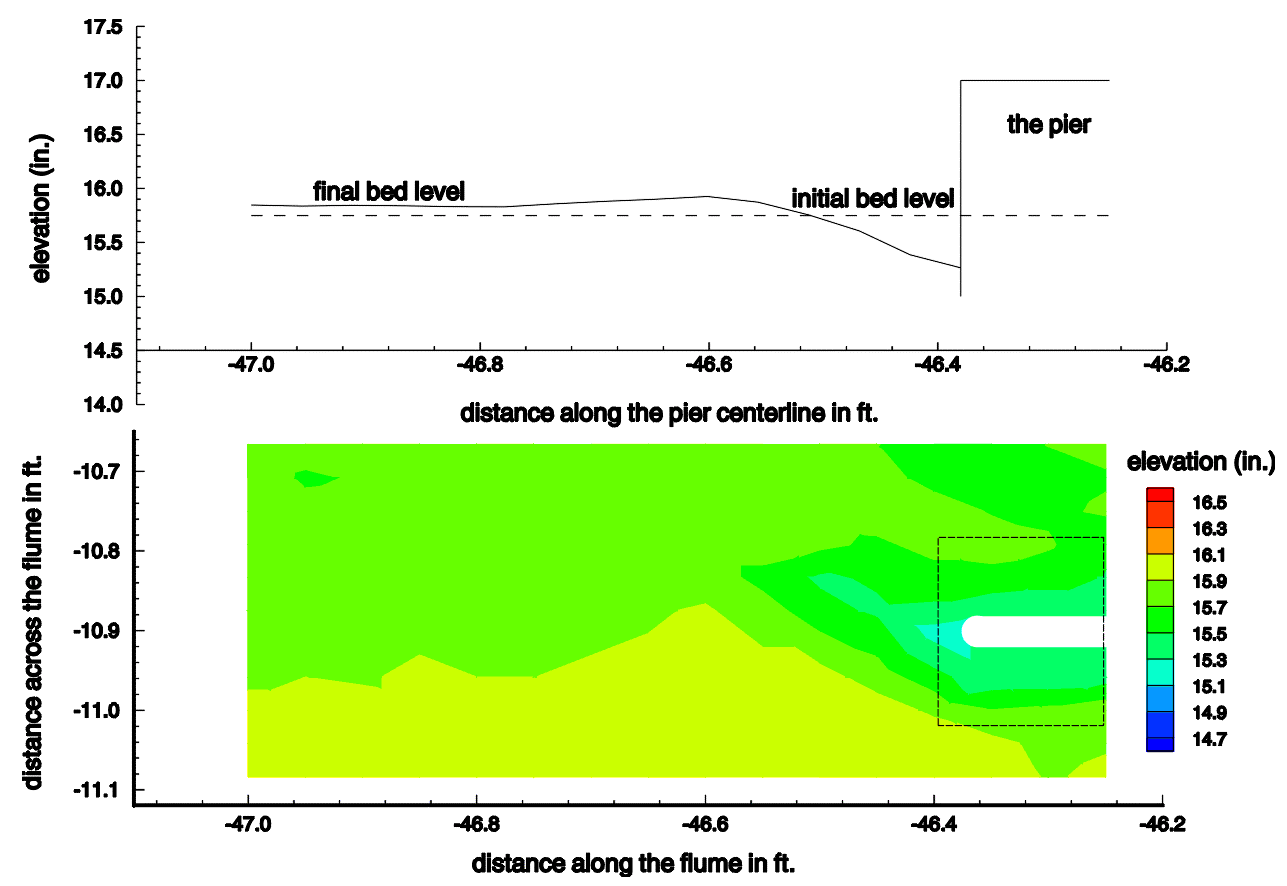

Fig. 4.4 Results for Run 3: a) bed-level profile along channel centerline (aligned with the pier, b) contours of bed-level in vicinity of pier.

the upstream pier $\left(y_{s} / b=2.5\right)$ such that the footing projected into the flow. Thus, the exposed footing did not limit the scour depth in this case, and an exposed footing cannot always be relied upon to inhibit scour-hole development. The footing of the downstream pier was not at all exposed. The flow intensity was somewhat larger than unity $\left(u / u_{c}=1.2\right)$, so live-bed conditions is assumed to have prevailed. Whether live-bed conditions alone explains the difference between the results of Runs 4 and 5 is not clear.

\subsubsection{Effect of slight skewness}

The second series of six runs focussed on the effect of a slight skewness. Two values of skewness, $5^{\circ}$ and $10^{\circ}$, were considered. Hydraulic conditions comparable to the first series of runs were generally chosen to permit comparison between the two series. Photographs of the final bed levels for two skewed-pier cases are shown in Fig. 4.7, showing both cases with and without exposed footings. In both cases, the more pronounced (in both extent as well as depth) scour is seen to occur in the vicinity of the downstream pier. The experimental parameters for the second series are summarized in Table 4.2.

Runs 5 and 6 shared similar hydraulic conditions (flow intensity, $u / u_{c}=1.3$, compared to a value of $u / u_{c}=1.2$ for Run 5) but while Run 5 had zero skew, Run 6 had a skewness of $5^{\circ}$. Although a deeper scour hole was expected and indeed was observed 

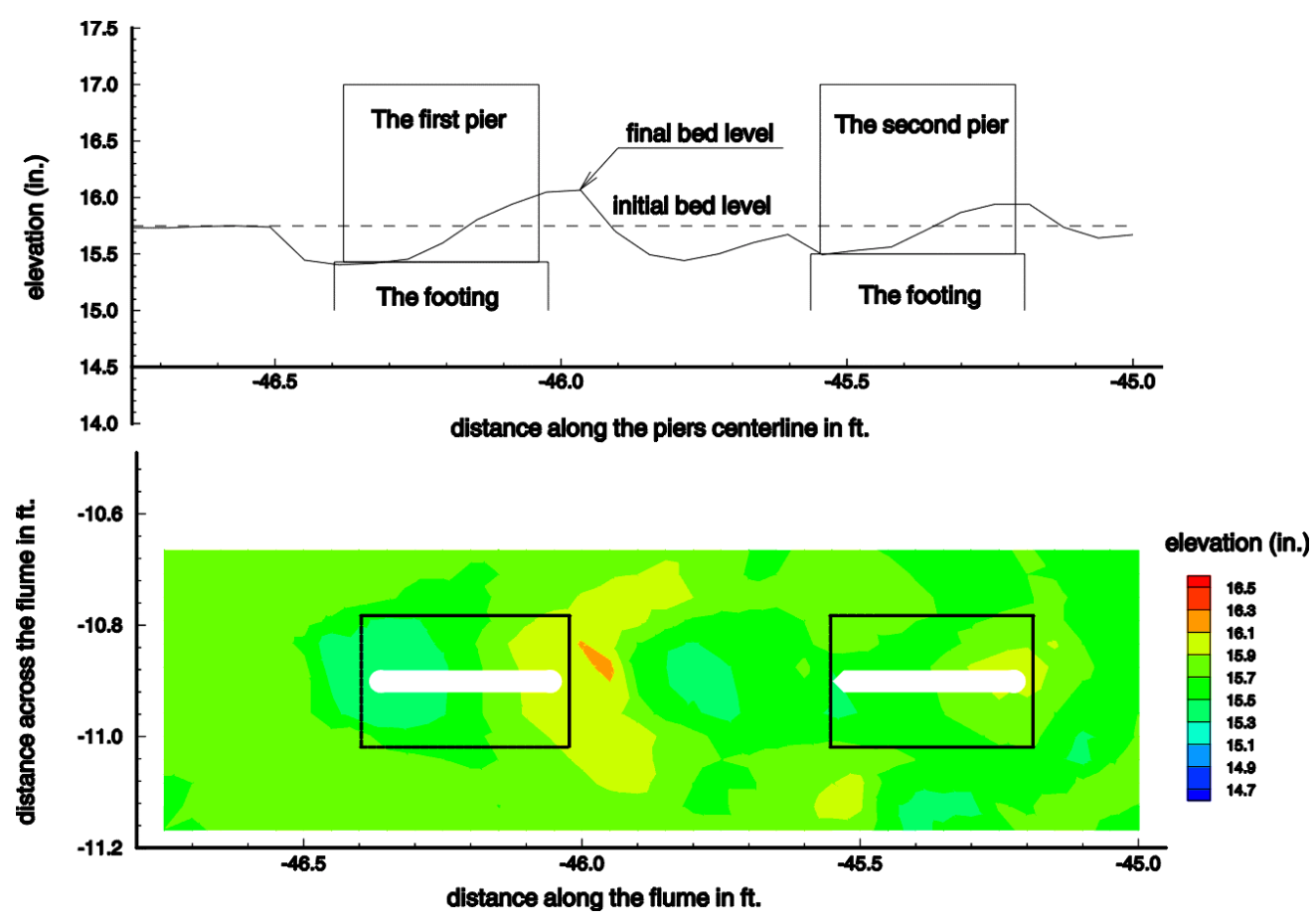

Fig. 4.5 Results from Run 4: a) bed-level profile along channel centerline (aligned with piers), b) contours of bed-level in vicinity of piers
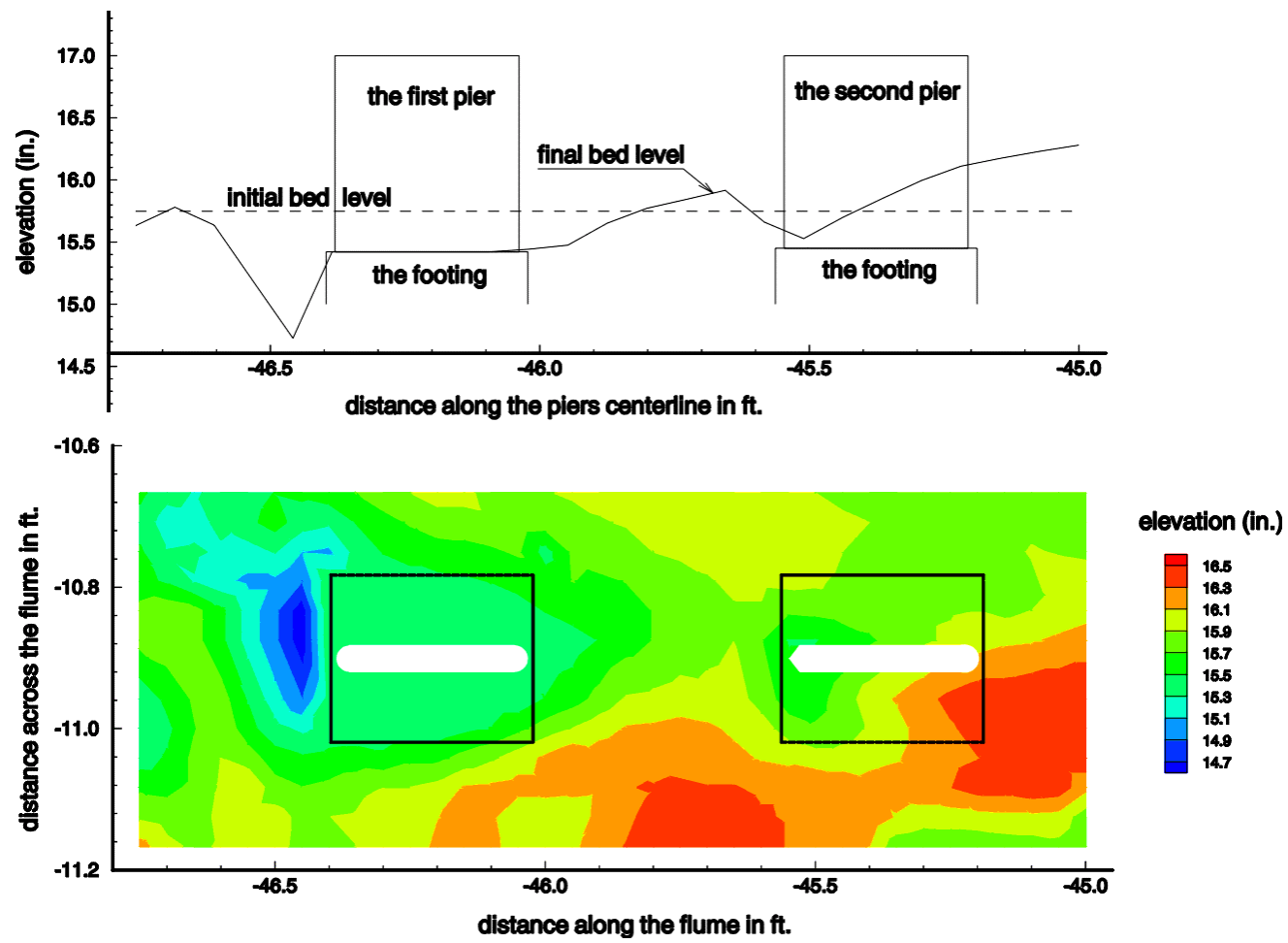

Fig. 4.6 Results of Run 5: a) bed-level profile along channel centerline (aligned with piers), b) contours of bed-level in vicinity of piers 


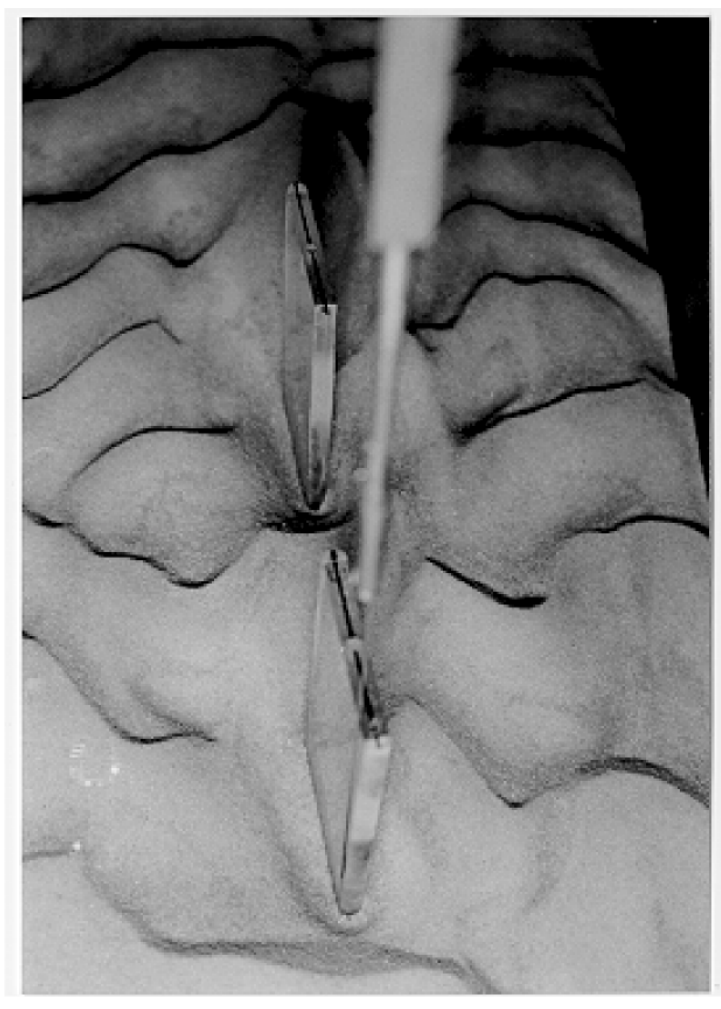

a)

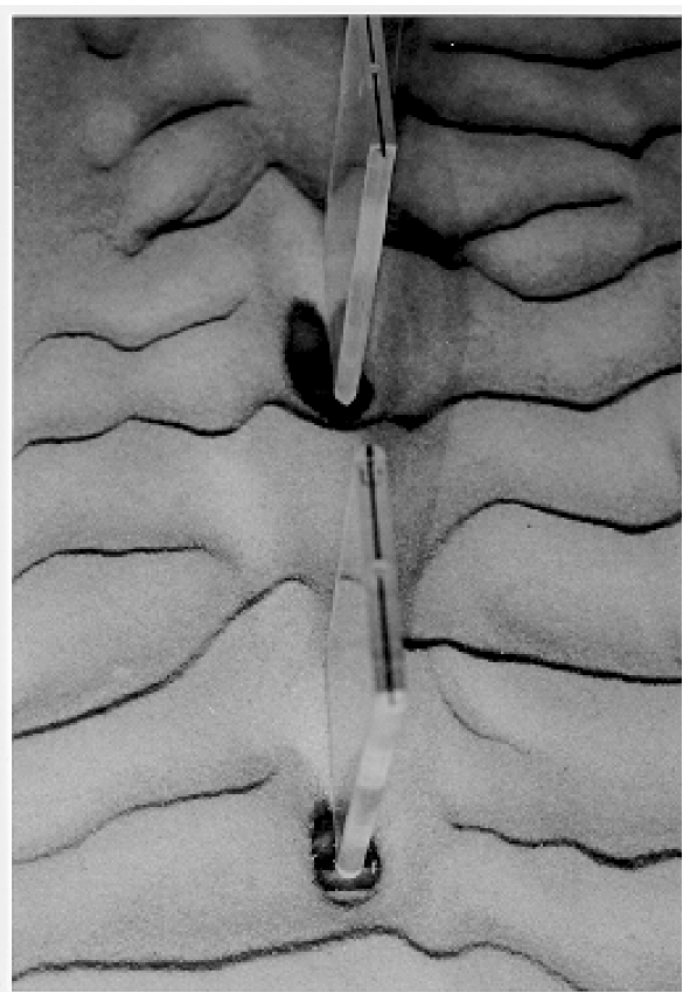

b)

Fig. 4.7 Photographs of final beds in cases with skewed piers: a) exposed footing (Run 6), b) unexposed footing (Run 7)

( $y_{s} / b=3.2$ compared with $y_{s} / b=2.5$ for Run 5), it is more pertinent to the present study that the location of the maximum scour depth occurred in the nose region of the downstream pier (Fig. 4.8). Even for a quite slight skewness, the location of maximum scour may therefore migrate away from the upstream pier nose region to the downstream pier nose region.

Run 7 was conducted with conditions similar to Run 6, except that the footing was lowered, so that the footing would not be exposed during the run and so would not play any role in arresting scour-hole development. The results in Fig. 4.9 show a somewhat increased $y_{s} / b=3.7$, and, like Run 6 , also a location of maximum scour that is associated more with the downstream pier than with the upstream pier. The location of maximum scour was however found to the side of the downstream pier, rather than at the nose.

The effect of clear-water conditions $\left(u / u_{c} \approx 0.9\right.$ ) was investigated in Runs 8 and 9, with Run 8 differing from Run 9 in having a lower footing elevation. Figs. 4.10 and 4.11 tend to show a weaker interaction between the two piers, with rather similar scour pattern for both upstream and downstream piers. In Run 8 with the lower footing, the region of deepest scour was found to the 'exposed' side of the both piers, while in Run 9, with a 
raised and hence exposed footing, was found in the nose region of the upstream pier. In both cases, $y_{s} / b$ was noticeably smaller than in the preceding live-bed cases with values of $y_{s} / b=2.6$ and 1.3 compared to values of 4 for Runs 6 and 7 . The role of the exposed footing in Run 9 in inhibiting the deepening of the scour hole is again noted.

The final two experiments in this series, the results of which are shown in Figs. 4.12 and 4.13 , were performed at a higher skew angle of $10^{\circ}$ and under live-bed conditions $\left(u / u_{c} \approx 1.3\right)$, Run 10 with a raised footing and Run 11 with a lowered footing. Except for a higher skew angle, the conditions for Run 10 were very similar to those for Run 6 . Somewhat surprisingly in view of the larger skew angle, Run 10 yielded a smaller $y_{s} / b=2$ compared to $y_{s} / b=3.2$ for Run 6 . The scour pattern for Run 10 is rather peculiar, with two scour holes just upstream of the downstream pier, the footing of which was exposed. In Run 11, with a lowered footing, the largest scour of the study was observed with $y_{s} / b=4.4$. Although placed at the lower elevation, the footing of the downstream pier was unexpectedly exposed. The scour pattern shows an extensive scour region between the two piers, which is consistent with the results of Run 10. In both Runs 10 and 11, the location of maximum scour is not found in the nose region of the upstream pier.

\section{Table 4.2 Parameters for the cases with skewed piers}

\begin{tabular}{|l|c|c|c|c|c|c|}
\hline parameter & Run 6 & Run 7 & Run 8 & Run 9 & Run 10 & Run 11 \\
\hline velocity, $u$ (fps) & 1.3 & 1.3 & 0.86 & 0.89 & 1.3 & 1.3 \\
\hline $\begin{array}{l}\text { elevation of footing with res- } \\
\text { pect to initial bed level, } z_{f} \text { (in) }\end{array}$ & -0.50 & -2.3 & -2.2 & -0.3 & -0.5 & -2.1 \\
\hline skewness angle $\left(^{\circ}\right)$ & 5 & 5 & 5 & 5 & 10 & 10 \\
\hline $\begin{array}{l}\text { pier Reynolds number, } \\
\operatorname{Re}_{b}=u b / v\left(\times 10^{3}\right)\end{array}$ & 4.8 & 4.8 & 3.3 & 3.3 & 4.8 & 4.8 \\
\hline Froude number, $F r=u / \sqrt{g y}$ & 0.38 & 0.40 & 0.26 & 0.27 & 0.39 & 0.40 \\
\hline flow intensity, $u / u_{c}$ & 1.3 & 1.3 & 0.86 & 0.89 & 1.3 & 1.3 \\
\hline $\begin{array}{l}\text { relative elevation of footing, } \\
z_{f} / b\end{array}$ & -1 & -4.6 & -4.4 & -0.6 & -1 & -4.2 \\
\hline
\end{tabular}




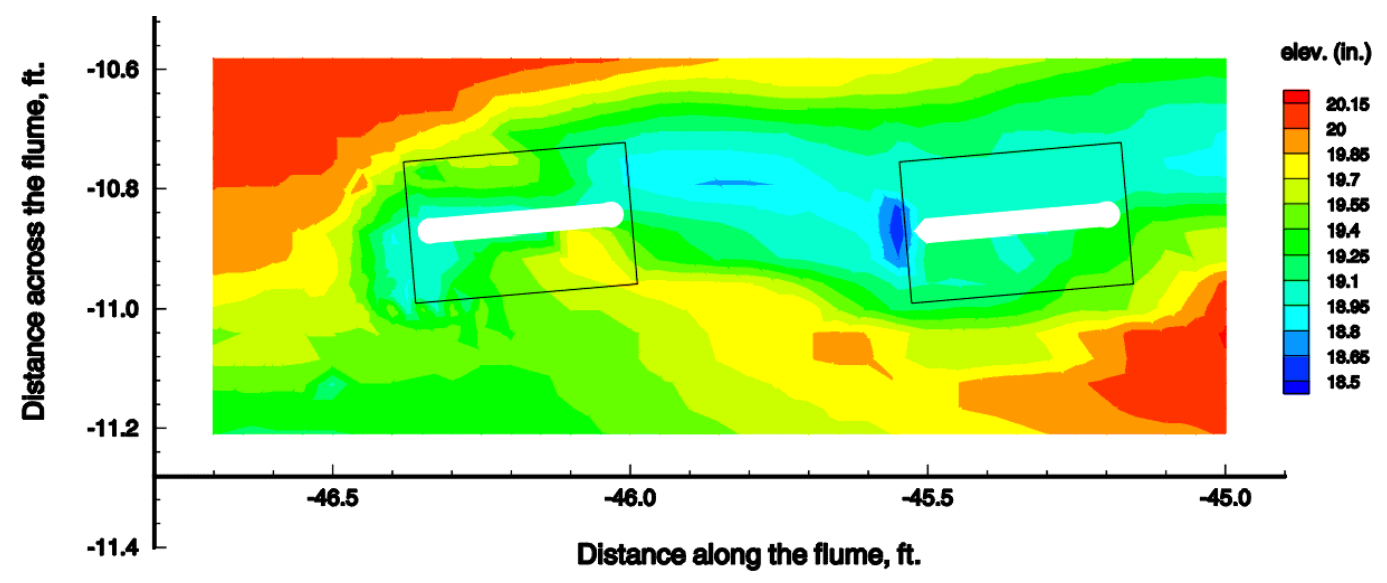

Fig. 4.8: Contours of final bed-levels for Run 6 (skewed piers)

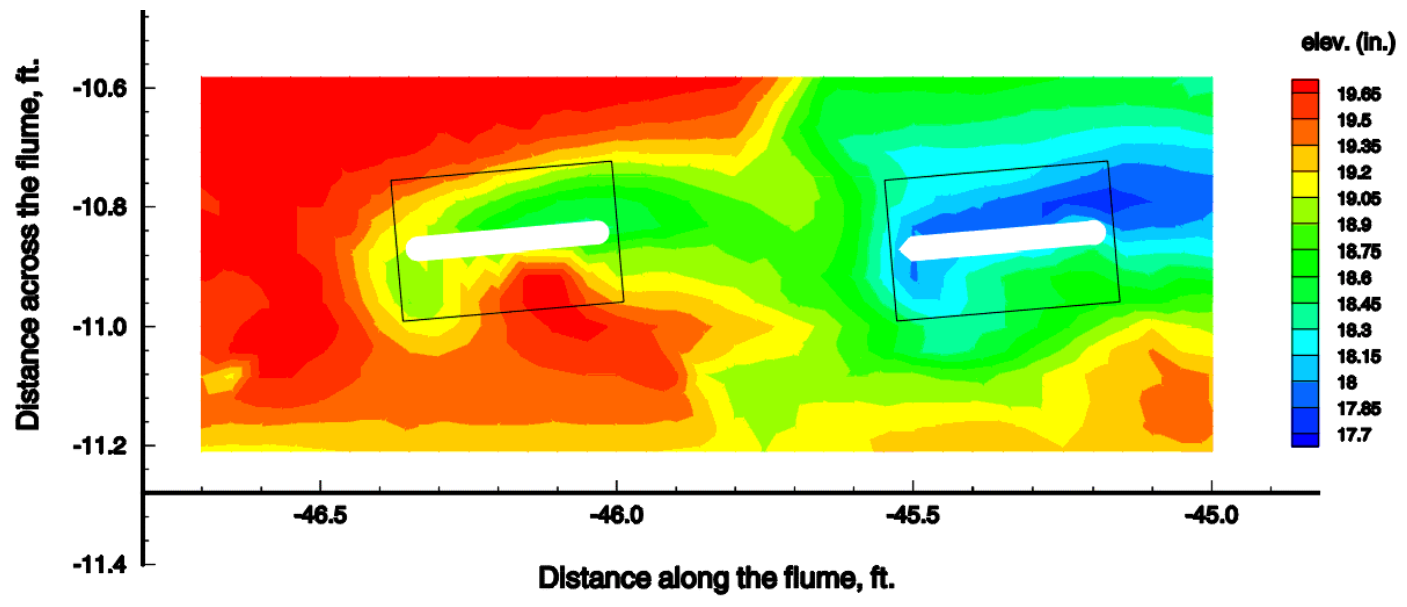

Fig. 4.9 Contours of final bed-levels for Run 7 (skewed piers)

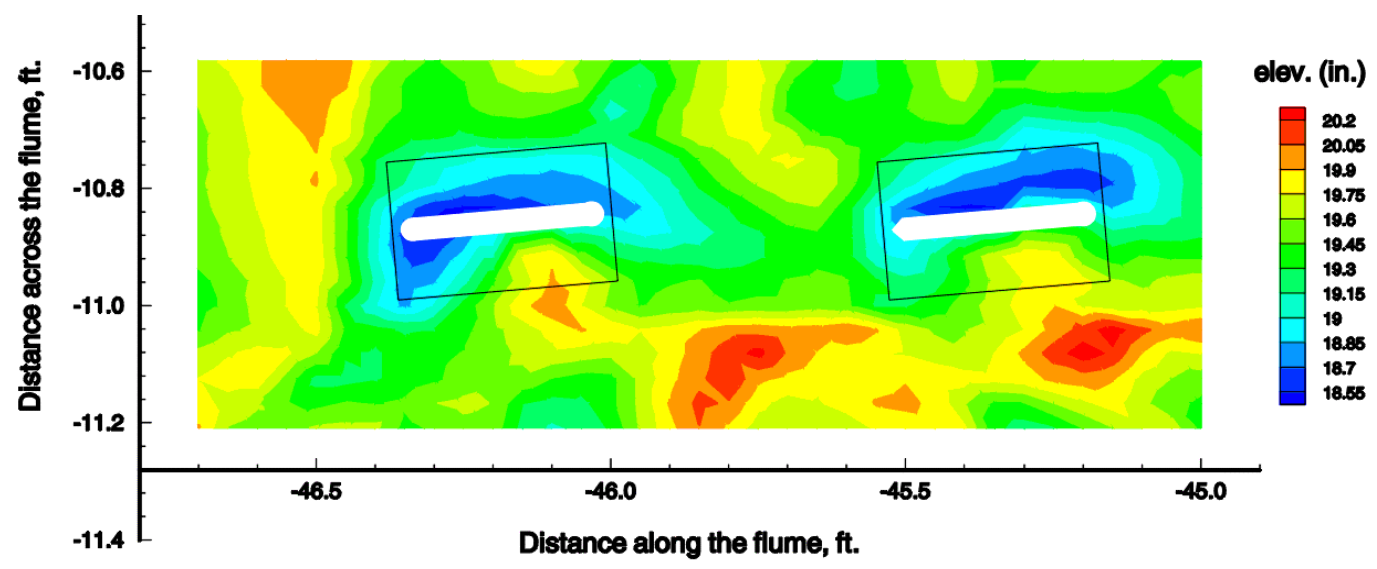

Fig. 4.10 Contours of final bed-levels for Run 8 (skewed piers) 


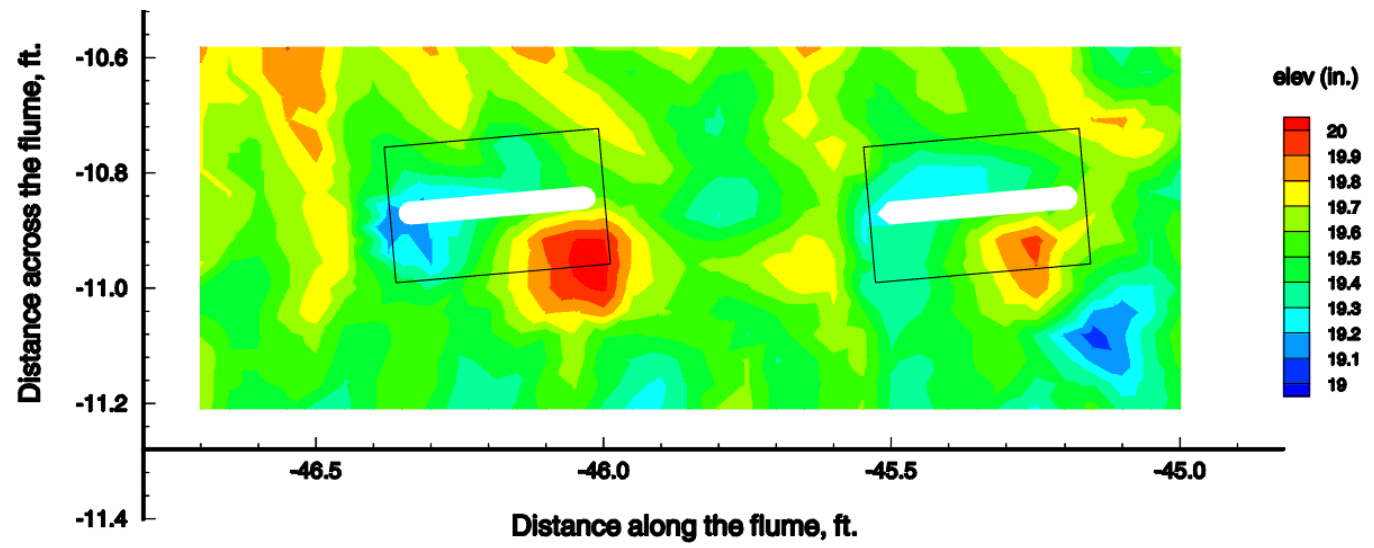

Fig. 4.11 Contours of final bed-levels for Run 9 (skewed piers)

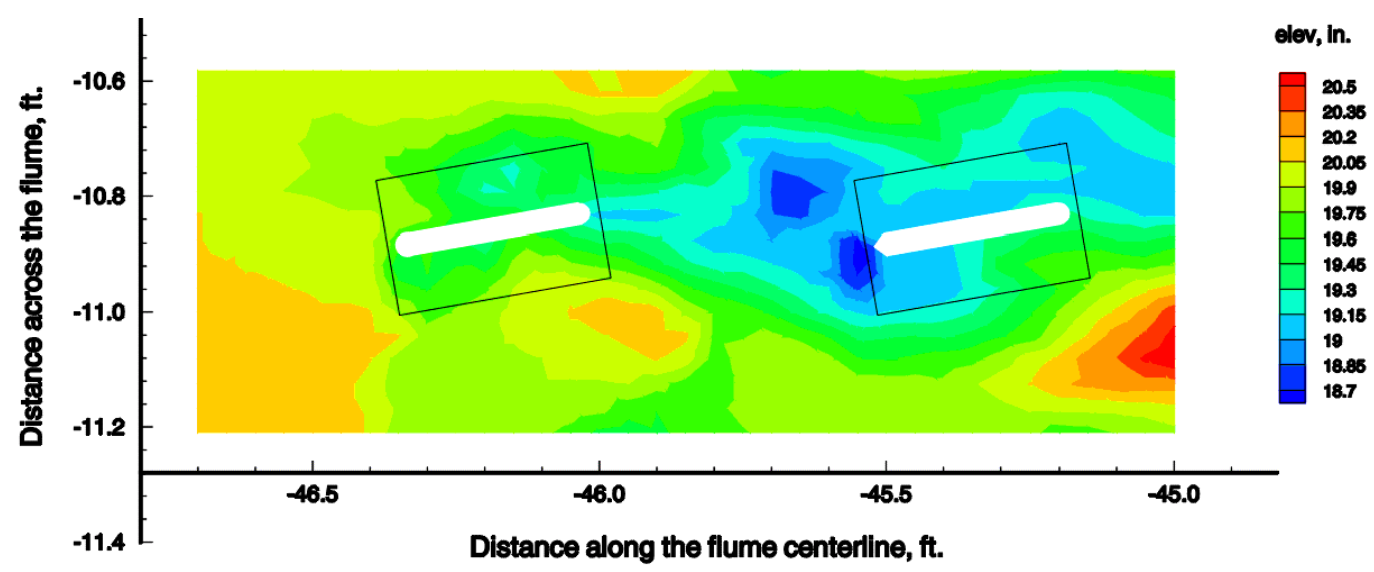

Fig. 4.12 Contours of final bed-levels for Run 10 (skewed piers)

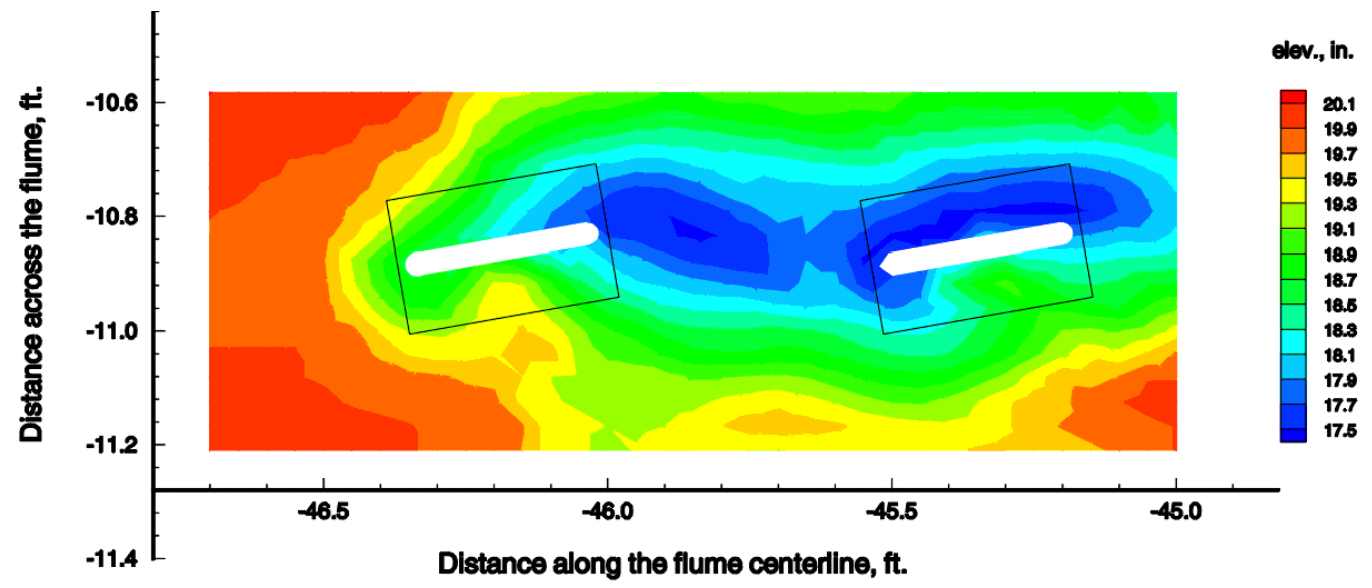

Fig. 4.13 Contours of final bed-levels for Run 11 (skewed piers) 


\subsection{Further discussion and data analysis}

\subsubsection{Comparison of scour depth results with standard equations}

The equilibrium scour depth, $y_{b}$, measured in all the runs were compared with predictions using three well-known pier-scour equations: i) the CSU or HEC-18, ii) the Melville-Sutherland, and iii) the Froehlich equations (see Sec. 2.3). Fig. 4.14 shows that the HEC-18 equation is generally conservative (all predictions are below the $45^{\circ}$ line), whereas the other two equations may actually underpredict the scour depth. In cases with zero skewness, the maximum values of $y_{s} / b$ was found to be less than 2.5 , which is generally consistent with what has been observed in previous studies. The maximum value of $y_{s} / b$ for skewed piers was approximately 4 , almost twice as large as the maximum value found for zero skew. For the small values of skewness angles considered in the study, this suggests that correction factors for small skewness may need to be larger than previously thought.

\subsubsection{Comparison of the maximum scour depth with the scour depth measured at upstream pier nose}

Since current design practice aligns piers with the flow and scour holes are deepest at the nose of the upstream pier, fixed-in-place scour-monitoring devices will most likely be installed at the nose of the upstream pier. It was therefore of interest to examine the observed maximum scour depth relative to the scour depth at the upstream pier nose to assess the possible magnitude of the 'error' in accepting the measurement of scourmonitoring devices. Fig. 4.15 shows that, in the cases with skew, the maximum scour depths were generally larger than the scour depths at the upstream pier nose. At the smaller skew angle of $5^{\circ}$, two cases were observed where the maximum scour depth did occur at the upstream pier nose. Even for a skew angle of $5^{\circ}$, however, the maximum scour depths may not always occur at the upstream pier nose, and, in those cases, the scour depth measured at the upstream pier nose will likely underestimate the maximum scour depth.

\subsubsection{The location of maximum scour depth relative to the piers}

It might be argued that only if the maximum scour depth occurs adjacent to a pier is it relevant from the practical standpoint of designing for pier scour. In the cases with skewed piers, the maximum scour depth may actually be found some distance away from a pier. A graphical depiction of the relative location of maximum scour is made difficult in these cases because, with varying skew angle, a scour hole at the same location in the fixed laboratory coordinate system may differ in the location relative to the pier location. In Fig. 4.16, a local coordinate system (denoted by $X^{*}$ and $Y^{*}$ ) with origin at the nose of either the upstream (with a $\mathrm{u}$-subscript) or downstream (with a d-subscript) is used, and the location of the observed maximum scour depth relative to the upstream or downstream pier is plotted for the different runs. 


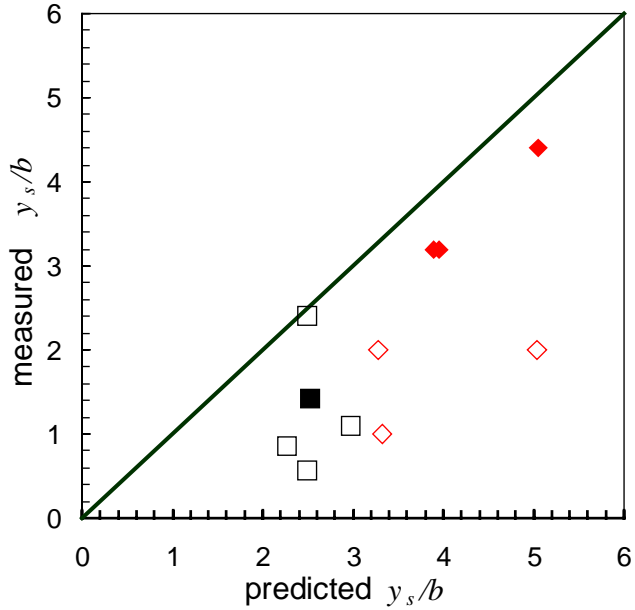

a)

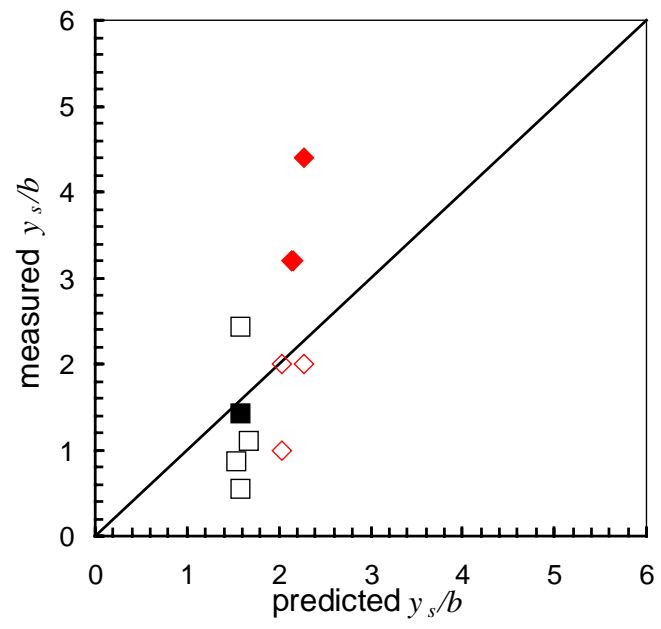

c)

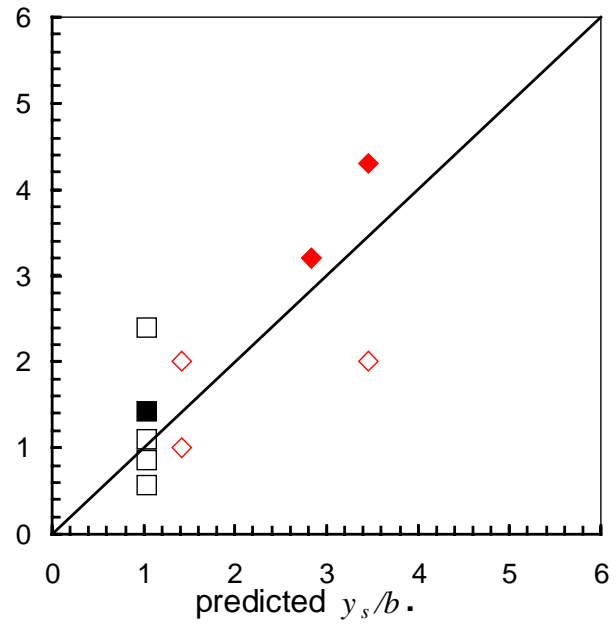

b)

Fig. 4.14 Comparison of measured and predicted scour depths according to

a) the CSU (HEC-18) formula,

b) the Melville-Sutherland formula, and c) the Froehlich formula.

$$
\begin{aligned}
& \square \text { zero skew } \\
& \diamond \text { non-zero skew }
\end{aligned}
$$

open symbols: footings exposed solid symbols: footings not exposed 


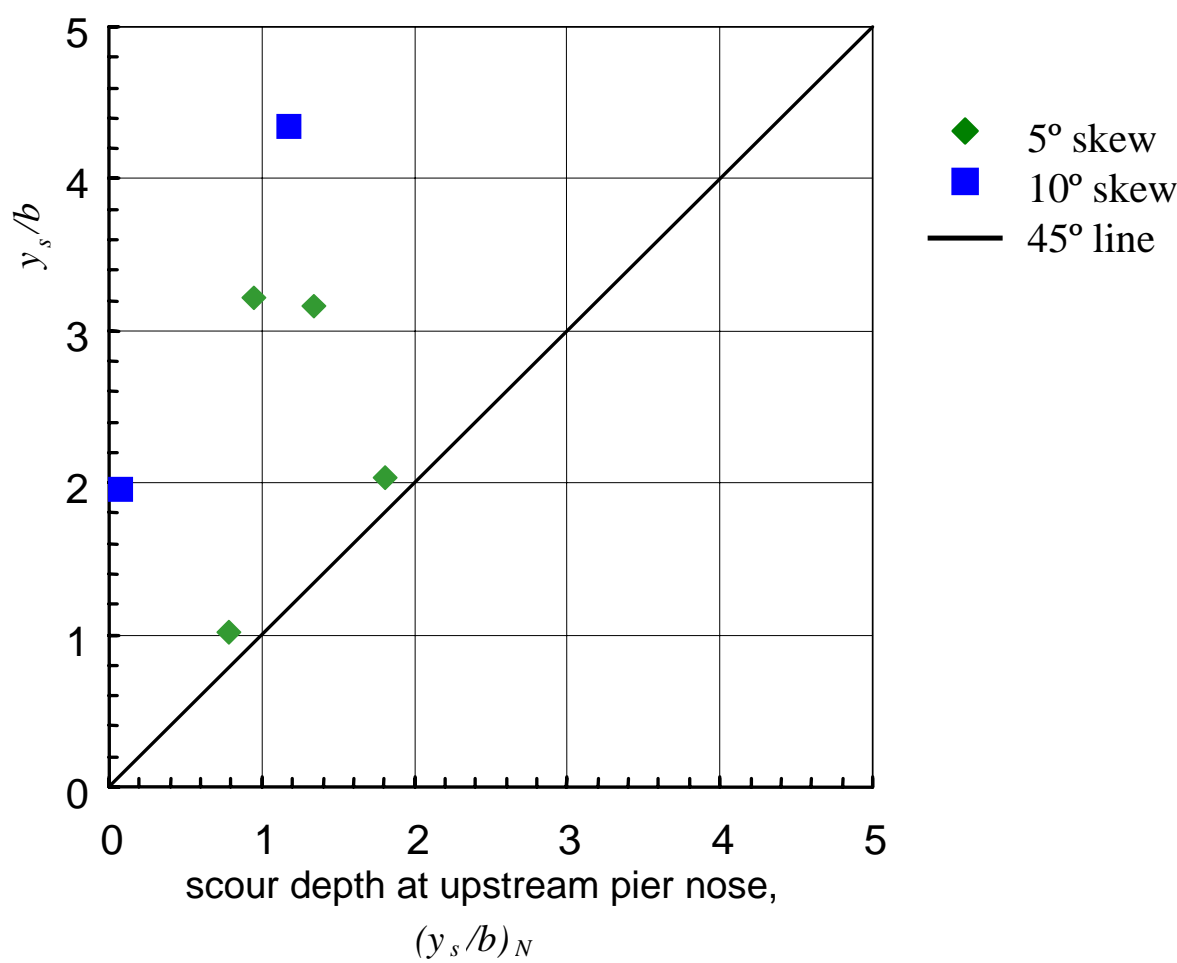

Fig. 4.15: Comparison of observed maximum scour depth with scour depth at upstream pier nose
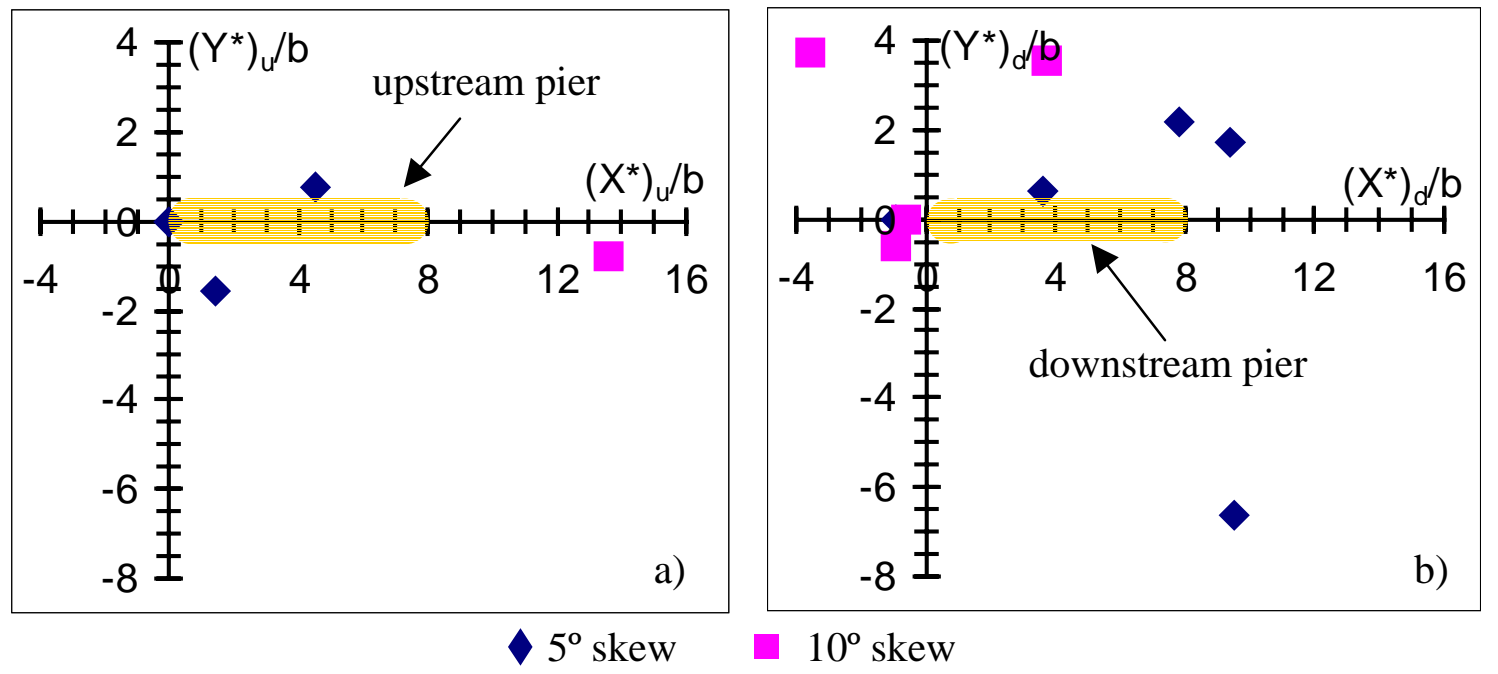

Fig. 4.16 Location of maximum scour (in local coordinates) relative to a) upstream pier, and to b) downstream piers 


\section{Chapter V: Summary and conclusions}

\subsection{Summary}

A laboratory study was conducted to study the local scour around single and double noncircular piers at slight angles of skew, with and without an exposed footing. The scaling of the model piers and hydraulic parameters was motivated by conditions expected in Indiana streams, in general, and in the two sites chosen for the field study, namely US 52 over the Wabash R. and SR 25 over Wildcat Creek. Both the flow depth and the sediment characteristics (a fairly uniform medium sand was used) were kept constant throughout the study. Clear-water and live-bed conditions were studied. Bed-level elevations in the vicinity of the pier(s) were obtained with a point gage after the channel was drained. The regions of the maximum scour could therefore be identified.

\subsection{Conclusions}

The main conclusions drawn from this study may be summarized as follows :

In the zero-skew case,

1. the location of maximum scour is found in the nose region of the upstream pier,

2. an exposed footing tends to have an inhibiting effect on scour hole development, at least under clear-water conditions; this inhibiting effect was less evident or entirely absent under live-bed conditions.

In the case of slight skewness, less than or equal to $10^{\circ}$ angle of attack,

1. the location of maximum scour is likely to migrate away from the nose region of the upstream pier, and is often found in the vicinity of the downstream pier,

2. correction factors for slight skewness may need to be significantly higher than has been previously recognized.

Based on the results of the study, the limitations of installing a single scour monitoring device in the nose region of the upstream pier should be recognized. For more reliable interpretation of continuous scour-monitoring data, corresponding continuous information regarding the extent of skewness would be highly desirable. 


\section{References}

1. Breusers, H. N. C. and Raudkivi, A. J. (1991). Scouring, A. A. Balkema, Rotterdam.

2. Brice, J. C. and Blodgett, J. C. (1978). Countermeasures for Hydraulic Problems at Bridges, Vols. 1 and 2, FHWA/RD-78-162\&163, Federal Highway Administration, U. S. Dept. of Transportation, Washington, D. C.

3. Chang, F. M. (1973). A Statistical Summary of the Cause and Cost of Bridge Failures, Federal Highway Administration, U. S. Dept. of Transportation, Washington, D. C.

4. Chiew, Y.-M. and Melville, B. W. (1996). Temporal Development of Local Scour at Bridge Piers, Proc. North American Water and Environment Congr., Anaheim, Calif.

5. Collins Engineers (1994). Bridge Inspection Report, US 52

6. Collins Engineers (1997). Bridge Inspection Report, Wildcat Creek.

7. Corps of Engineers (1968). Flood Plain Information, Wabash River and Wildcat Creek.

8. Ettema, R., Melville, B. W. and Barkdoll, B. (1996). Pier-Width and Local-Scour Depth, Proc. North American Water and Environment Congr., Anaheim, Calif.

9. FEMA (1980). Flood Insurance Study, County of Tippecanoe, Unincorporated Areas.

10. Fotherby, L. and Jones, J. S. (1993). The Influence of Exposed Footings on Pier Scour Depths, Proc. Hydraulic Engineering, '93, San Francisco, July 25 - 30, ed. H.-W. Shen, S. T. Su, and F. Wen, pp. 922-927.

11. Froehlich, D. (1988). Analysis of on-site measurements of scour at piers, in Hydraulic Engineering - Proc. 1988 National Conf. Hydraulic Engineering, ASCE, New York.

12. Jones, J. S. (1984). Comparison of Prediction Equations for Bridge Pier and Abutment Scour, Transportation Research Record, 950, Sept. 24 - 26.

13. Jones, J. S., Kilgore, R. T., and Mistichelli, M. P. (1992). Effects of Footing Location on Bridge Pier Scour, J. Hydraulic Eng., 118, No. 2, pp. 280 - 290.

14. Lagasse, P. F., Schall, J. D., Johnson, F., Richardson, E. V., Richardson, J. E., and Chang, F. (1991). Stream Stability at Highway Structures, Rept. FHWA-IP-90-014, Hydraulic Engineering Circular, No. 18, U.S. Dept. of Transportation.

15. Lagasse, P. F., Richardson, E. V., Schall, J. D., and Price, G. R. (1997). Instrumentation for Measuring Scour at Bridge Piers and Abutments, NCHRP, Rept. 396, National Academy Press, Washington D. C.

16. Landers, M. N. and Mueller, D. S. (1996). Scour Processes Observed in Field Data, Proc. North American Water and Environment Congr., Anaheim, Calif.

17. Melville, B. W. (1984). Live-Bed Scour at Bridge Piers, J. Hydraulic Eng., 110, No. 9 , pp. $1234-1247$.

18. Melville, B. W. and Raudkivi, A. J. (1996). Effects of Foundation Geometry on Bridge Pier Scour, J. Hydraulic Eng., 122, No. 4, pp. 203 - 209.

19. Melville, B. W. and Sutherland, A. J. (1988). Design Method for Local Scour at Bridge Piers, J. Hydraulic Eng., 114, No. 10, October, pp. 1210 - 1226.

20. Mostafa, E. A., Yassan, A. A., Ettema, R., and Melville, B. W. (1993). Local Scour at Skewed Piers, Proc. Hydraulic Engineering, '93, San Francisco, July 25 - 30, ed. H.W. Shen, S. T. Su, and F. Wen, pp. $1037-1042$. 
21. Parola, A. C., Mahavadi, S. K., Brown, B. M., and El Khoury, A. (1996). Effects of Rectangular Foundation Geometry on Local Pier Scour, J. Hydraulic Eng., 122, No. 1, pp. $35-40$.

22. Raudkivi, A. J. (1990). Loose Boundary Hydraulics, Pergamon Press, Oxford.

23. Rhodes, J. and Trent, R. (1993). Economics of Floods, Scour and Bridge Failures, Proc. Hydraulic Engineering, '93, San Francisco, July 25 - 30, ed. H.-W. Shen, S. T. $\mathrm{Su}$, and F. Wen, pp. 928-933.

24. Richardson, E. V., Harrison, L. J., Richardson, J. R., and Davis, S. R. (1993). Evaluating Scour at Bridges, $2^{\text {nd }}$ ed., FHWA-IP-90-017, Hydraulic Engineering Circular, No. 18, U.S. Dept. of Transportation.

25. Roberson, J. and Crowe, C. T. (1993). Engineering Fluid Mechanics, $5^{\text {th }}$ ed., Houghton-Mifflin, Boston.

26. Shen, H. W., Schneider, V. R., and Karaki, S. (1969). Local Scour around Bridge Piers, J. Hydraulics Div., Proc. ASCE, 95, HY6, November, pp. 1919 - 1940. 